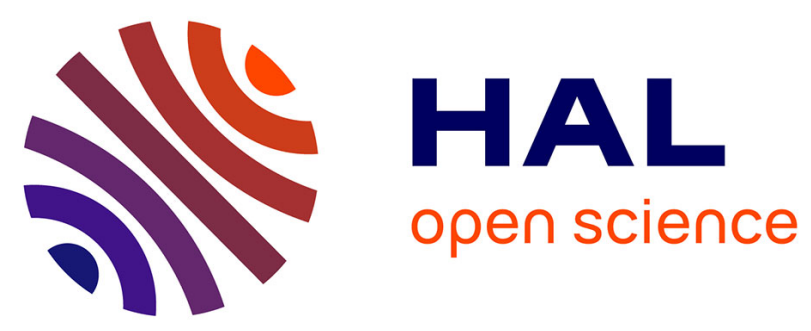

\title{
Dicationic stilbazolium salts: Structural, thermal, optical, and ionic conduction properties
}

Pradip K Bhowmik, Jung J Koh, David King, Haesook Han, Benoît Heinrich, Bertrand Donnio, Daniel Zaton, Alfonso Martinez-Felipe

\section{To cite this version:}

Pradip K Bhowmik, Jung J Koh, David King, Haesook Han, Benoît Heinrich, et al.. Dicationic stilbazolium salts: Structural, thermal, optical, and ionic conduction properties. Journal of Molecular Liquids, 2021, 341, pp.117311. 10.1016/j.molliq.2021.117311 . hal-03407930

\section{HAL Id: hal-03407930 \\ https://hal.science/hal-03407930}

Submitted on 28 Oct 2021

HAL is a multi-disciplinary open access archive for the deposit and dissemination of scientific research documents, whether they are published or not. The documents may come from teaching and research institutions in France or abroad, or from public or private research centers.
L'archive ouverte pluridisciplinaire $\mathbf{H A L}$, est destinée au dépôt et à la diffusion de documents scientifiques de niveau recherche, publiés ou non, émanant des établissements d'enseignement et de recherche français ou étrangers, des laboratoires publics ou privés. 


\section{Dicationic stilbazolium salts: Structural, thermal, optical, and ionic conduction properties}

Pradip K. Bhowmik ${ }^{a}{ }^{*}$, Jung J. Koha, David Kinga, Haesook Han ${ }^{a}$, Benoît Heinrich ${ }^{\text {b }}$, Bertrand Donnio $^{b}$, Daniel Zatonc, Alfonso Martinez-Felipe ${ }^{c, d}$

\footnotetext{
${ }^{a}$ Department of Chemistry and Biochemistry, University of Nevada Las Vegas, $4505 \mathrm{~S}$. Maryland Parkway, Box 454003, Las Vegas, NV 89154, USA. Corresponding author' E-mail address: pradip.bhowmik@unlv.edu (P.K. Bhowmik).

${ }^{\mathrm{b}}$ Institut de Physique et Chimie des Matériaux de Strasbourg (IPCMS), UMR 7504, CNRS-Université de Strasbourg, Strasbourg F-67034, France

${ }^{c}$ Chemical and Materials Engineering Group, School of Engineering, University of Aberdeen, King's College, Old Aberdeen AB24 3UE, UK

${ }^{d}$ Centre for Energy Transition, University of Aberdeen, Aberdeen, Scotland AB24 3UE, UK
}

Cite as J. Mol. Liq. 2021, 341, 117311

Publication Date: August 20, 2021

https://doi.org/10.1016/j.molliq.2021.117311

\section{Highlights}

-Dicationic stilbazolium salts were prepared by quaternization and metathesis reactions.

-They displayed polymorphism but not mesomorphism and had high thermal stability.

-They exhibited higher absolute quantum yields in the powdered state than in solution.

-They showed notable values of short-range conductivity through amorphous regions.

-They have the potential as advanced materials in optoelectronic devices.

Keywords: Dicationic stilbazolium salts, Differential scanning calorimetry, Polarized optical microscopy, Variable temperature X-ray diffraction, UV-vis spectroscopy, Luminescence, lonic conductivity

Abstract: Two series of new dicationic stilbazolium salts containing tosylate and triflimide counterions, respectively, were synthesized and characterized by spectroscopic techniques and elemental analysis. Despite of their promesogenic structures, none of these salts are mesomorphous, 
and instead they solely exhibit crystalline polymorphism, as deduced from differential scanning calorimetry, polarizing optical microscopy and variable temperature $\mathrm{X}$-ray measurements. These salts were also found to be highly thermally stable with decomposition temperatures occurring well above $300{ }^{\circ} \mathrm{C}$, and up to $367^{\circ} \mathrm{C}$ for the triflimide salts, as determined by thermogravimetric analysis. UV-Vis absorption and photoluminescent properties were examined in both solution and in the solid state. They exhibited higher absolute quantum yields in the powdered state than in solution. The dielectric response was evaluated by impedance spectroscopy, revealing notable values of short-range conductivity in triflimide salts through amorphous regions. Our work demonstrates the potential of these new stilbazolium salts as advanced materials in optoelectronic devices, with performances that can be tailored by molecular design of the spacer's flexibility and choice of counter anions.

\section{Introduction}

Ionic liquids (ILs) are low-temperature melting salts (with melting points ranging below room temperature to as high as $100^{\circ} \mathrm{C}$ ) that have drawn much attention over the past years due to their ever-increasing potential applications as substitutes for volatile organic solvents in organic synthesis [1], [2], [3], solvents for high-temperature reactions [4], electrochemical applications in photovoltaic cells, fuel cells and batteries [5], [6], [7], [8], [9], [10], [11], high-temperature lubricants [12], liquid-liquid extractions [13], [14], [15], and mass spectrometric applications [16], [17], [18], among others. The properties of ILs can be easily and independantly tuned by changing the chemical structures of both cations and anions, and design and synthesis of new salts leading to ILs continue to open new forefronts in chemistry, physics, biology and material science and technology [19], [20], [21], [22], [23], [24].

In general, multi-charged ILs have been shown to have a greater range of physical properties than their monocationic counterparts, such as higher density, glass transition, melting point, surface tension, and shear viscosity [25]. Like traditional ILs, they can be task-specific ionic liquids depending on their chemical structures [26], [27], [28], [29], [30], [31], [32], [33], [34]. Notable recent examples include tetracationic acidic organic salt based on 1,4-diazabicyclo[2], [2], [2]octane (DABCO) that are used as catalyst in the Knoevenagel condensation reactions in water [29], [30]. They can also be used for gas chromatographic separations as stationary phases [32], [33], [34]. Since the number of possible combinations of cationic and anionic moieties in multi-charged ILs is greater than those of monocationic ILs, multi-charged ILs can be considered as an extension to the structural variations of ILs. Most of the synthesized dicationic ILs comprise in their chemical structures ammonium [35], [36], [37], phosphonium [34], imidazolium [38], pyridinium [39] or pyrrolidinium [40] cation to explore their physical properties. D'Anna and Noto compiled a prominent review article on this subject [41]. However, material chemists face great challenges to synthesize multi-charged ILs because of strong, long-range intermolecular interactions. The incorporation of bulky organic anions such as tosylate ('OTs) and bis(trifluoromethylsulfonyl)imide ( $\left.{ }^{-} \mathrm{N}(\mathrm{Tf})_{2}\right)$ not only decrease the melting transitions but also increase the thermal stabilities of ILs.

Armstrong et al. [42], [43], [44] reported the effect of chemical structural modifications on the physicochemical properties of symmetrical tricationic ILs containing ${ }^{-} \mathrm{N}(\mathrm{Tf})_{2}$, hexafluorophosphate $\left({ }^{-} \mathrm{PF}_{6}\right)$, tetrafluoroborate $\left({ }^{-} \mathrm{BF}_{4}\right)$, and trifluoromethanesulfonate $\left(\mathrm{TfO}^{-}\right)$. The densities of ILs with similar cationic moieties are affected by the counterions in the order ${ }^{-} \mathrm{N}(\mathrm{Tf})_{2}>{ }^{-} \mathrm{PF}_{6}>\mathrm{TfO}^{-}>{ }^{-} \mathrm{BF}_{4}$; and the thermal decomposition temperatures of tricationic ILs are higher (often $>400{ }^{\circ} \mathrm{C}$ ) than those of monocationic ionic liquids with a few exceptions (e.g. 1-ethyl-3-methyl-imidazolium salt with triflimide 
counterion has a thermal stability of $400^{\circ} \mathrm{C}$ ). The melting transitions of tricationic ILs are also affected by the flexibility of the central core systems; for example, ILs with more flexible core structures exhibit lower melting points when compared with those having more rigid core structures. The solubility of these salts in water and heptane is very similar to that of monocationic and dicationic ILs and depends largely on the choice of anions [42], [43]. Furthermore, the mesitylene core with bis- and trisimidazolium salts exhibits liquid-crystalline $(L C)$ properties with various organic anions $\left(-\mathrm{I},{ }^{-} \mathrm{BF}_{4}\right.$, and $\left.{ }^{-} \mathrm{N}(\mathrm{Tf})_{2}\right)$ [44] what are known as ILCs [45], [46], [47], [48], [49], [50].

Organic salts having fluorescent properties are also receiving considerable attention due to their unique attributes. They not only exhibit tunable electronic and physical characteristics, including solution-based and solid-state fluorescence, but also offer other advantages ascribed specifically to their charged nature. For example, benzobis(imidazolium) salts are an excellent class of such organic salts [51]. Multicharged salts also possess greater promises as therapeutics (e.g., inhibition of protein kinase C) in several animal models than the corresponding monocationic salts [52], [53].

Stilbazoles and stilbazolium salts are a class of organic crystalline materials that exhibit many interesting physical, optical, and optoelectronic properties, which have been studied extensively [54], [55], [56], [57], [58]. For examples, 4- $N, N$-dimethylamino-4'- $N$ '-methyl-stilbazolium with tosylate, $p$-hydroxybenzenesulfonate, $p$-aminobenzenesulfonate or $p$ dimethylaminobenzenesulfonate anion are used in a variety of nonlinear optical devices [59], [60]. Due to their heterocyclic structures, they have potential to be used as cationic species via quaternization reaction.

Recently, we reported the promising properties of luminescent tricationic salts based on mesitylene cores containing trans-4-octyloxy-4-stilbazolium moieties with various counterions [61]. In this study, we now describe the synthesis of new dicationic stilbazolium salts with ditosylate counterions from the quaternization of trans-4-octyloxy-4'-stilbazole with $\underline{\alpha}, \omega$-methylene ditosylates in acetonitrile, as illustrated in Scheme 1. Additional dicationic stilbazolium salts are synthesized via metathesis reaction from the corresponding ditosylate salt with lithium triflimide in methanol. Their chemical structures, thermal, morphological and optical properties were characterized by using various experimental techniques. Additionally, we have also correlated some selected dicationic stilbazolium salts with their dielectric and ionic conductivity response, using electrochemical impedance spectroscopy, to evaluate their potential application in electrochemical devices.

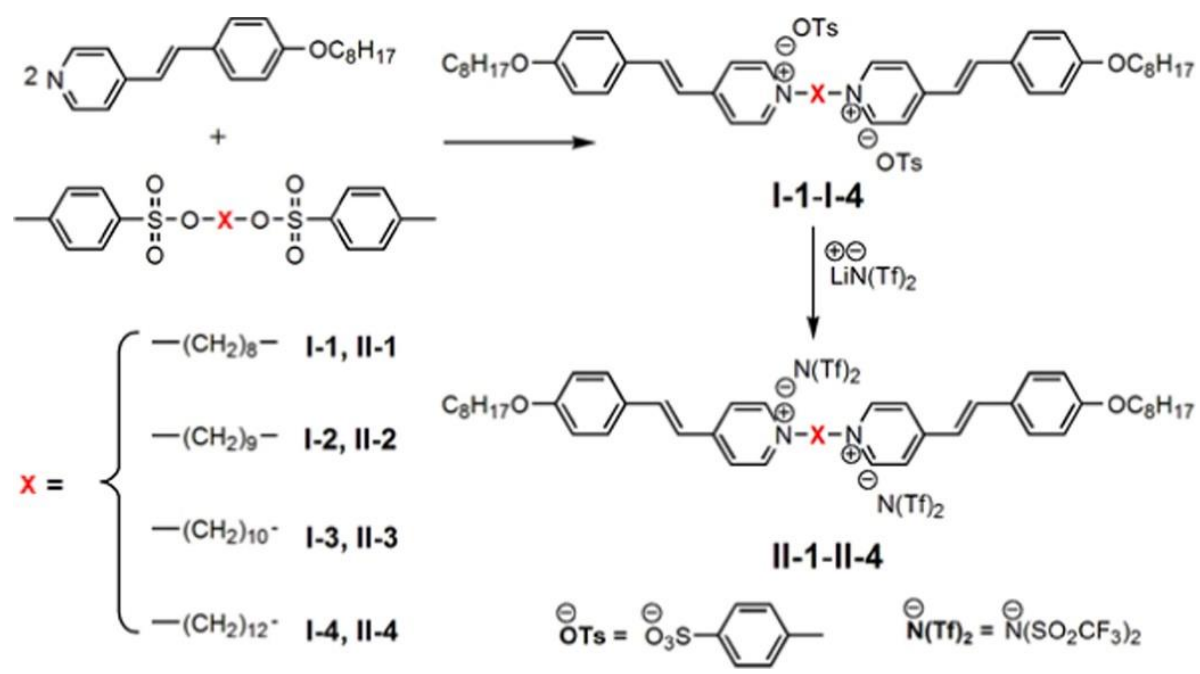

Scheme 1. Synthesis of dicationic stilbazolium dicationic salts containing tosylate and triflimide counterions. 


\section{Materials and methods}

\subsection{General information}

${ }^{1} \mathrm{H},{ }^{19} \mathrm{~F}$ and ${ }^{13} \mathrm{C}$ NMR spectra of the dicationic stilbazolium salts in $\mathrm{CDCl}_{3}$ or acetone- $d_{6}$ were recorded by using a VNMR 400 spectrometer operating at 400,376 and $100 \mathrm{MHz}$, respectively, at room temperature and chemical shifts were referenced to tetramethylsilane (TMS) for proton and carbon nuclei and trichlorofluoromethane ( $\left.\mathrm{CFCl}_{3}\right)$ for fluorine nuclei. Differential scanning calorimetry (DSC) measurements were conducted on a TA module DSC Q200 series in nitrogen at heating and cooling rates of $10^{\circ} \mathrm{C} / \mathrm{min}$. The temperature axis of the DSC thermograms was calibrated before using the reference standard of high purity indium and sapphire. The polymorphism of these salts was examined using a polarized optical microscopy (POM, Nikon, Model Labophot 2) equipped with crossed polarizers. Variable-temperature XRD measurements of four salts were carried out for both heating and cooling cycles, with temperature steps of 20 and $10^{\circ} \mathrm{C}$, respectively. Samples were exposed to X-ray beam irradiation for about one hour at each temperature. The XRD patterns as a function of temperature were obtained using a linear monochromatic Cu-K $K_{\alpha 1}$ beam $(\lambda=1.5405 \AA)$, using a sealed-tube generator ( $900 \mathrm{~W}$ ) equipped with a bent quartz monochromator. The crude powder was filled in Lindemann capillaries of $1 \mathrm{~mm}$ diameter and $10 \mu \mathrm{m}$ wall thickness. The diffraction patterns were recorded with a curved INEL CPS120 counter gas-filled detector linked to a data acquisition computer; periodicities up to $60 \AA$ could be measured, and the sample temperature controlled to within $\pm 0.05^{\circ} \mathrm{C}$ from 20 to $250^{\circ} \mathrm{C}$. In each case, exposure times were varied from 1 to $24 \mathrm{~h}$.

The thermal stability of the salts was assessed by thermogravimetric analysis (TGA), using a TGA Q50 instrument at a heating rate of $10^{\circ} \mathrm{C} / \mathrm{min}$, under nitrogen atmosphere. The UV-Vis absorption spectra of the dicationic salts in organic solvents were recorded with a Varian Cary 3 Bio UVVis spectrophotometer also at room temperature. Their photoluminescence spectra both in organic solvents and in thin films were recorded with a Perkin-Elmer LS 55 luminescence spectrometer with a xenon lamp light source. Absolute quantum yields of salts I-1, I-4, II-3 and II-4 in both acetonitrile solution and in the bulk (powder) were measured with a Horiba Fluorolog fluorimeter equipped with an integrating sphere.

The conductivity of selected salts was studied by complex impedance spectroscopy. Indium Tin Oxide cells, ITO (SG100A080uG180, Instec), were filled by capillary with the samples in the melt state. Cells had $A=100 \mathrm{~mm} 2$ active areas, with $100 \Omega$ resistance and $v=8 \mu \mathrm{m}$ thickness, and their capacitance, $\mathrm{CO}$, was then calculated as,

$\mathrm{C}_{0}=\varepsilon_{0} \mathrm{~A} / \mathrm{v}=1.10675 * 10^{-10} \mathrm{~F}$

where $\varepsilon_{0}=8.854 \cdot 10^{-12} \mathrm{~F} \cdot \mathrm{m}^{-1}$, is the dielectric permittivity of vacuum.

A PARSTAT MC multichannel potentiostat (Ametek) was connected to the cells, which were then placed on a Linkham TMS 91 hot stage for temperature control, with $\pm 0.1{ }^{\circ} \mathrm{C}$ accuracy. The dielectric response was measured in isothermal frequency sweeps between $10^{6} \mathrm{~Hz}$ and $0.1 \mathrm{~Hz}$, applying $\mathrm{V}_{\mathrm{rms}}=1000 \mathrm{mV}$ amplitude alternating electric fields in the absence of bias electric fields. The measurements were carried out in isothermal steps of $2{ }^{\circ} \mathrm{C}$, cooling from the isotropic melt to room temperature. Additional variable-temperature Fourier-transform infrared spectroscopy measurements, FT-IR, were performed by filling a few mg of the salts from the melt between two $\mathrm{KBr}$ discs, and then placing them in the Linkham TMS 91 hot stage $\left( \pm 0.1^{\circ} \mathrm{C}\right.$ accuracy). The stage was then assembled in a Shimadzu Tracer 100 spectrometer operating in transmittance mode in the $4000-$ 
$400 \mathrm{~cm}^{-1}$ range, and with $4 \mathrm{~cm}^{-1}$ accuracy. Samples were cooled down from the melt to room temperature, and measurements were taken in isothermal steps of $2{ }^{\circ} \mathrm{C}$, similarly to the dielectric experiments.

\subsection{Synthesis}

The dicationic stilbazolium salts (I-1 - I-4) were prepared by the reaction of trans-4-octyloxy-4stilbazole with $\underline{\alpha}, \omega$-methylene ditosylates and then followed by metathesis reaction of the corresponding ditosylates salts with lithium triflimide salt to yield the dicationic stilbazolium ditriflimide salts (II-1- II-4), as shown in Scheme 1.

\subsubsection{General procedure for synthesis of dicationic stilbazolium salts I-1 - I-4}

The synthetic protocol of the salts was slightly modified from the reported procedure [62] shown in Scheme 1. Trans-4-octyloxy-4'-stilbazole [63] (1.32 g, $4.30 \mathrm{mmol}, 2$ equiv), 1,9-methylene ditosylate [64], [65] (1.00 g, $2.15 \mathrm{mmol}, 1$ equivalent) and acetonitrile $(40 \mathrm{~mL})$, were placed in a roundbottomed flask fitted with a condenser and the solution was stirred on heating to reflux for $48 \mathrm{~h}$. After cooling to room temperature, the precipitate was collected by vacuum filtration and the crude product was recrystallized from acetonitrile. The yellow crystalline product was dried in vacuo at $100{ }^{\circ} \mathrm{C}$ for $12 \mathrm{~h}$ to give $1.83 \mathrm{~g}(1.68 \mathrm{mmol}$, yield $=78 \%)$ of $\mathbf{I - 2}$. Other salts in the series were recrystallized from methanol.

Anal. Calcd for salt I-1, $\mathrm{C}_{64} \mathrm{H}_{84} \mathrm{~N}_{2} \mathrm{O}_{8} \mathrm{~S}_{2}$ (1073.52): C,72.30; H, 8.21; N, 2.48; S, 5.69. Found: C, 70.64; $\mathrm{H}$, 8.19; $\mathrm{N}, 2.54 ; \mathrm{S}, 5.52 ;{ }^{1} \mathrm{H}$ NMR $\left(400 \mathrm{MHz}, \mathrm{CDCl}_{3}, \mathrm{ppm}\right) \delta=0.89$ (t, $\left.6 \mathrm{H},-\mathrm{CH}_{2} \mathrm{CH}_{3}\right), 1.28-1.48(\mathrm{~m}, 28 \mathrm{H}$, $-\mathrm{CH}_{\text {aliphatic }}$ ), 1.77 (q, $4 \mathrm{H},-\mathrm{OCH}_{2} \mathrm{CH}_{2} \mathrm{CH}_{2}-$ ) $, 1.92\left(\mathrm{br}, 4 \mathrm{H}, \mathrm{CH}_{\text {aliphatic }}\right), 2.27\left(\mathrm{~s}, 6 \mathrm{H}, \mathrm{C}_{\text {arom }} \mathrm{CH}_{3}\right), 3.96(\mathrm{t}, 4 \mathrm{H}$, $\left.-\mathrm{OCH}_{2} \mathrm{CH}_{2}-\right)$, $4.52\left(\mathrm{t}, 4 \mathrm{H},-\mathrm{CH}_{2} \mathrm{CH}_{2} \mathrm{~N}-\right), 6.83(\mathrm{~d}, 2 \mathrm{H},-\mathrm{CH}=\mathrm{CH}-), 6.88\left(\mathrm{~d}, 4 \mathrm{H}, H_{\text {arom }}\right), 7.10\left(\mathrm{~d}, 4 \mathrm{H}, H_{\text {arom }}\right)$, $7.47\left(\mathrm{~d}, 4 \mathrm{H}, H_{\text {arom }}\right), 7.50(\mathrm{~d}, 2 \mathrm{H},-\mathrm{CH}=\mathrm{CH}-), 7.81\left(\mathrm{~m}, 8 \mathrm{H}, H_{\text {arom }}\right), 9.03\left(\mathrm{~d}, 4 \mathrm{H}\right.$. $\left.H_{\text {arom }}\right) ;{ }^{13} \mathrm{C} \mathrm{NMR}(100 \mathrm{MHz}$, $\mathrm{CDCl}_{3}$, ppm) $\delta=14.1,21.3,22.7,25.0,26.0,27.5,29.2,29.3,29.4,30.9,31.8,60.4,68.4,115.2,119.9$, $123.7,126.1,127.3,128.7,130.1,139.1,141.3,144.5,144.6,153.3,161.6$.

Anal. Calcd for salt I-2, $\mathrm{C}_{65} \mathrm{H}_{86} \mathrm{~N}_{2} \mathrm{O}_{8} \mathrm{~S}_{2}$ (1087.54): C, 71.79; H, 7.97; N, 2.58; S, 5.90. Found: C, 69.03; H, 8.08; N, 2.52; $\mathrm{S}, 5.70 ;{ }^{1} \mathrm{H}$ NMR $\left(400 \mathrm{MHz}, \mathrm{CDCl}_{3}, \mathrm{ppm}\right) \delta=0.89\left(\mathrm{t}, 6 \mathrm{H},-\mathrm{CH}_{2} \mathrm{CH}_{3}\right), 1.23-1.46(\mathrm{~m}, 30 \mathrm{H}$, $-\mathrm{CH}_{\text {aliphatic }}$ ), 1.76 (q, $4 \mathrm{H},-\mathrm{OCH}_{2} \mathrm{CH}_{2} \mathrm{CH}_{2}-$ ), 1.90 (br, 4H, $\left.\mathrm{CH}_{\text {aliphatic }}\right), 2.29\left(\mathrm{~s}, 6 \mathrm{H}, \mathrm{C}_{\text {arom }} \mathrm{CH}_{3}\right), 3.94$ (t, $4 \mathrm{H}$, $\left.-\mathrm{OCH}_{2} \mathrm{CH}_{2}-\right), 4.51\left(\mathrm{t}, 4 \mathrm{H},-\mathrm{CH}_{2} \mathrm{CH}_{2} \mathrm{~N}-\right), 6.83(\mathrm{~d}, 2 \mathrm{H},-\mathrm{CH}=\mathrm{CH}-), 6.88\left(\mathrm{~d}, 4 \mathrm{H}, H_{\text {arom }}\right), 7.12\left(\mathrm{~d}, 4 \mathrm{H}, H_{\text {arom }}\right)$, $7.48\left(\mathrm{~d}, 4 \mathrm{H}, H_{\text {arom }}\right), 7.51(\mathrm{~d}, 2 \mathrm{H},-\mathrm{CH}=\mathrm{CH}-), 7.84\left(\mathrm{~m}, 8 \mathrm{H}, H_{\text {arom }}\right), 8.98\left(\mathrm{~d}, 4 \mathrm{H}\right.$. $\left.H_{\text {arom }}\right) ;{ }^{13} \mathrm{C} \mathrm{NMR}(100 \mathrm{MHz}$, $\mathrm{CDCl}_{3}$, ppm) $\delta=14.0,21.3,22.7,25.3,26.0,27.8,28.1,29.2,29.4,31.1,31.8,60.3,68.3,115.1,119.9$, $123.8,126.1,127.4,128.7,130.2,139.1,141.3,144.4,144.5,153.4,161.5$.

Anal. Calcd for salt I-3, $\mathrm{C}_{66} \mathrm{H}_{88} \mathrm{~N}_{2} \mathrm{O}_{8} \mathrm{~S}_{2}$ (1101.57): C, 71.96; H, 8.05; N, 2.54; S, 5.82. Found: C, 69.55; H, 8.10; $\mathrm{N}, 2.38 ; \mathrm{S}, 5.75 ;{ }^{1} \mathrm{H}$ NMR $(400 \mathrm{MHz}, \mathrm{CDCl}, \mathrm{ppm}) \delta=0.89\left(\mathrm{t}, 6 \mathrm{H},-\mathrm{CH}_{2} \mathrm{CH}_{3}\right), 1.20-1.45(\mathrm{~m}, 32 \mathrm{H}$, $-\mathrm{CH}_{\text {aliphatic }}$ ), 1.78 (q, $4 \mathrm{H},-\mathrm{OCH}_{2} \mathrm{CH}_{2} \mathrm{CH}_{2}-$ ), 1.90 (br, $\left.4 \mathrm{H}, \mathrm{CH}_{\text {aliphatic }}\right), 2.28\left(\mathrm{~s}, 6 \mathrm{H}, \mathrm{C}_{\text {arom }} \mathrm{CH}_{3}\right), 3.96(\mathrm{t}, 4 \mathrm{H}$, $\left.-\mathrm{OCH}_{2} \mathrm{CH}_{2}-\right)$, $4.52\left(\mathrm{t}, 4 \mathrm{H},-\mathrm{CH}_{2} \mathrm{CH}_{2} \mathrm{~N}-\right), 6.85(\mathrm{~d}, 2 \mathrm{H},-\mathrm{CH}=\mathrm{CH}-), 6.88\left(\mathrm{~d}, 4 \mathrm{H}, H_{\text {arom }}\right), 7.10\left(\mathrm{~d}, 4 \mathrm{H}, H_{\text {arom }}\right)$, $7.48\left(\mathrm{~d}, 4 \mathrm{H}, H_{\text {arom }}\right), 7.52$ (d, $\left.2 \mathrm{H},-\mathrm{CH}=\mathrm{CH}-\right), 7.79$ (d, $\left.4 \mathrm{H}, H_{\text {arom }}\right), 7.85$ (d, $\left.4 \mathrm{H}, H_{\text {arom }}\right), 8.92$ (d, 4H. $\left.H_{\text {arom }}\right) ;{ }^{13} \mathrm{C} \mathrm{NMR}\left(100 \mathrm{MHz}, \mathrm{CDCl}_{3}, \mathrm{ppm}\right) \delta=14.1,21.3,22.7,25.5,26.0,27.9,28.2,29.2,29.4,31.1$, $31.8,60.5,68.4,115.2,119.9,123.8,126.1,127.3,128.7,130.2,139.2,141.5,144.2,144.4,153.5$, 161.6 .

Anal. Calcd for salt I-4, $\mathrm{C}_{68} \mathrm{H}_{92} \mathrm{~N}_{2} \mathrm{O}_{8} \mathrm{~S}_{2}$ (1129.62): C, 72.30; H, 8.21; N, 2.48; S, 5.68. Found: C, 71.25; $\mathrm{H}$, 8.24; N, 2.47; S, 5.48; ${ }^{1} \mathrm{H}$ NMR $\left(400 \mathrm{MHz}, \mathrm{CDCl}_{3}, \mathrm{ppm}\right) \delta=0.89\left(\mathrm{t}, 6 \mathrm{H},-\mathrm{CH}_{2} \mathrm{CH}_{3}\right), 1.18-1.50(\mathrm{~m}, 34 \mathrm{H}$, $-\mathrm{CH}_{\text {aliphatic }}$ ), 1.77 (q, $4 \mathrm{H},-\mathrm{OCH}_{2} \mathrm{CH}_{2} \mathrm{CH}_{2}-$ ) $, 1.88\left(\mathrm{br}, 4 \mathrm{H}, \mathrm{CH}_{\text {aliphatic }}\right), 2.28\left(\mathrm{~s}, 6 \mathrm{H}, \mathrm{C}_{\text {arom }} \mathrm{CH}_{3}\right), 3.96(\mathrm{t}, 4 \mathrm{H}$, $-\mathrm{OCH}_{2} \mathrm{CH}_{2}-$ ), $4.52\left(\mathrm{t}, 4 \mathrm{H},-\mathrm{CH}_{2} \mathrm{CH}_{2} \mathrm{~N}-\right.$ ) $, 6.86\left(\mathrm{~d}, 4 \mathrm{H}, H_{\text {arom }}\right), 6.88(\mathrm{~d}, 2 \mathrm{H},-\mathrm{CH}=\mathrm{CH}-), 7.10\left(\mathrm{~d}, 4 \mathrm{H}, H_{\text {arom }}\right)$, 
$7.48\left(\mathrm{~d}, 4 \mathrm{H}, H_{\text {arom }}\right), 7.52$ (d, $\left.2 \mathrm{H},-\mathrm{CH}=\mathrm{CH}-\right), 7.80$ (d, $\left.4 \mathrm{H}, H_{\text {arom }}\right), 7.86$ (d, $\left.4 \mathrm{H}, H_{\text {arom }}\right), 8.93$ (d, $\left.4 \mathrm{H}, H_{\text {arom }}\right) ;{ }^{13} \mathrm{C}$ NMR $\left(100 \mathrm{MHz}, \mathrm{CDCl}_{3}, \mathrm{ppm}\right) \delta=14.1,21.3,22.7,25.7,26.0,28.2,28.4,28.5,29.2,29.4$, $31.3,31.8,60.6,68.4,115.2,119.8,123.8,126.1,127.3,128.6,130.2,139.0,141.6,144.4,144.6,153.5$, 161.7. The ${ }^{1} \mathrm{H}$ and ${ }^{13} \mathrm{C}$ NMR spectra of the salts $\mathrm{I}-1-\mathrm{I}-4$ are provided in Figs. S1 $-\mathrm{S} 4$.

\subsubsection{General procedure for synthesis of dicationic stilbazolium salts II-1 - II-4}

Salts II-1 - II-4 were prepared by metathesis from the respective tosylate salts with excess of lithium bis(trifluoromethylsulfonyl)imide in methanol on heating to reflux for $24 \mathrm{~h}$. For a representative example, the salt $\mathbf{~} \mathbf{- 2}(0.850 \mathrm{~g}, 0.782 \mathrm{mmol})$ and lithium bis(trifluoromethylsulfonyl)imide $(494 \mathrm{mg}$, $1.72 \mathrm{mmol}$ ), were dissolved in $20 \mathrm{~mL}$ of methanol and the solution was stirred on heating to reflux for $48 \mathrm{~h}$. The excess methanol was removed by a rotary evaporator, and then the residual solid was washed thoroughly with water to remove excess lithium triflimide and lithium tosylate. The step was repeated twice until all the tosylate counterions were completely exchanged to triflimide counterions, as confirmed from the analysis of ${ }^{1} \mathrm{H}$ NMR spectrum. The crude product was recrystallized from isopropanol to provide fine, yellow crystals, which were then subsequently dried in vacuo at $80^{\circ} \mathrm{C}$ for $24 \mathrm{~h}$ to give $0.782 \mathrm{~g}(0.599 \mathrm{mmol}$, yield $=77 \%)$. Other salts in the series were recrystallized from methanol.

Anal. Calcd for salt II-1, $\mathrm{C}_{54} \mathrm{H}_{70} \mathrm{~N}_{4} \mathrm{O}_{10} \mathrm{~F}_{12} \mathrm{~S}_{4}$ (1291.40): C, 50.22; $\mathrm{H}, 5.46 ; \mathrm{N}, 4.34 ; \mathrm{S}, 9.93$. Found: $\mathrm{C}, 50.21$; $\mathrm{H}, 5.85 ; \mathrm{N}, 4.42 ; \mathrm{S}, 10.30 ;{ }^{1} \mathrm{H}$ NMR $\left(400 \mathrm{MHz}\right.$, acetone- $\left.d_{6}, \mathrm{ppm}\right) \delta=0.89\left(\mathrm{t}, 6 \mathrm{H},-\mathrm{CH}_{2} \mathrm{CH}_{3}\right), 1.29-1.51(\mathrm{~m}$, $\left.28 \mathrm{H},-\mathrm{CH}_{\text {aliphatic }}\right), 1.80$ (q, $4 \mathrm{H},-\mathrm{OCH}_{2} \mathrm{CH}_{2} \mathrm{CH}_{2}-$ ), 2.11 (s, $\left.4 \mathrm{H}, \mathrm{CH}_{\text {aliphatic }}\right), 4.09$ (t, $4 \mathrm{H},-\mathrm{OCH}_{2} \mathrm{CH}_{2}-$ ), 4.69 (t, $4 \mathrm{H},-\mathrm{CH}_{2} \mathrm{CH}_{2} \mathrm{~N}-$ ), 7.05 (d, $\left.4 \mathrm{H}, H_{\text {arom }}\right), 7.39(\mathrm{~d}, 2 \mathrm{H},-\mathrm{CH}=\mathrm{CH}-), 7.72\left(\mathrm{~d}, 4 \mathrm{H}, H_{\text {arom }}\right), 8.00(\mathrm{~d}, 2 \mathrm{H}$, $-\mathrm{CH}=\mathrm{CH}-), 8.25\left(\mathrm{~d}, 4 \mathrm{H}, H_{\text {arom }}\right), 8.91\left(\mathrm{~d}, 4 \mathrm{H}, H_{\text {arom }}\right) ;{ }^{13} \mathrm{C}$ NMR $\left(100 \mathrm{MHz}\right.$, acetone- $\left.d_{6}, \mathrm{ppm}\right) \delta=14.3$, $23.3,26.7,29.2-30.6\left(C_{\text {aliphatic }}\right.$ and acetone- $\left.d_{6}\right), 31.9,32.5,61.5,68.9,116.0,121.1,124.6,128.6,131.1$, $142.6,144.8,155.3,162.6$.

Anal. Calcd for salt II-2, $\mathrm{C}_{55} \mathrm{H}_{72} \mathrm{~N}_{4} \mathrm{O}_{10} \mathrm{~F}_{12} \mathrm{~S}_{4}$ (1305.43): $\mathrm{C}, 50.61 ; \mathrm{H}, 5.56 ; \mathrm{N}, 4.29 ; \mathrm{S}, 9.82$. Found: $\mathrm{C}, 50.62$; $\mathrm{H}, 5.64 ; \mathrm{N}, 4.42 ; \mathrm{S}, 9.84 ;{ }^{1} \mathrm{H}$ NMR $\left(400 \mathrm{MHz}, \mathrm{CDCl}_{3}, \mathrm{ppm}\right) \delta=0.82\left(\mathrm{t}, 6 \mathrm{H},-\mathrm{CH}_{2} \mathrm{CH}_{3}\right), 1.18-1.41(\mathrm{~m}, 30 \mathrm{H}$, $-\mathrm{CH}_{\text {aliphatic }}$ ), 1.70 (q, $\left.4 \mathrm{H},-\mathrm{OCH}_{2} \mathrm{CH}_{2} \mathrm{CH}_{2}-\right), 1.87\left(\mathrm{br}, 4 \mathrm{H}, \mathrm{CH}_{\text {aliphatic }}\right), 3.90\left(\mathrm{t}, 4 \mathrm{H},-\mathrm{OCH}_{2} \mathrm{CH}_{2}-\right)$ ) $4.31(\mathrm{t}, 4 \mathrm{H}$, $-\mathrm{CH}_{2} \mathrm{CH}_{2} \mathrm{~N}-$ ), 6.84 (d, $\left.4 \mathrm{H}, \mathrm{H}_{\text {arom }}\right), 6.88(\mathrm{~d}, 2 \mathrm{H},-\mathrm{CH}=\mathrm{CH}-), 7.48\left(\mathrm{~d}, 4 \mathrm{H}, \mathrm{H}_{\text {arom }}\right), 7.54(\mathrm{~d}, 2 \mathrm{H},-\mathrm{CH}=\mathrm{CH}-$ ), 7.79 (d, $\left.4 \mathrm{H}, H_{\text {arom }}\right), 8.45$ (d, $\left.4 \mathrm{H}, H_{\text {arom }}\right) ;{ }^{13} \mathrm{C} \mathrm{NMR}\left(100 \mathrm{MHz}, \mathrm{CDCl}_{3}, \mathrm{ppm}\right) \delta=14.1,22.6,25.2,26.0,27.7$, 27.9, 29.1, 29.2, 29.3, 31.0, 31.8, 60.8, 68.3, 115.2, 119.3, 123.7, 127.0, 130.3, 142.4, 143.3, 154.2, 161.4 .

Anal. Calcd for salt II-3, $\mathrm{C}_{56} \mathrm{H}_{74} \mathrm{~N}_{4} \mathrm{O}_{10} \mathrm{~F}_{12} \mathrm{~S}_{4}$ (1319.46): C, 50.98; $\mathrm{H}, 5.65 ; \mathrm{N}, 4.25 ; \mathrm{S}, 9.72$. Found: $\mathrm{C}, 51.30$; $\mathrm{H}, 5.90 ; \mathrm{N}, 4.42 ; \mathrm{S}, 9.74 ;{ }^{1} \mathrm{H}$ NMR $\left(400 \mathrm{MHz}, \mathrm{CDCl}_{3}, \mathrm{ppm}\right) \delta=0.89\left(\mathrm{t}, 6 \mathrm{H},-\mathrm{CH}_{2} \mathrm{CH}_{3}\right), 1.20-1.49(\mathrm{~m}, 32 \mathrm{H}$, $\left.-\mathrm{CH}_{\text {aliphatic }}\right), 1.78\left(\mathrm{q}, 4 \mathrm{H},-\mathrm{OCH}_{2} \mathrm{CH}_{2} \mathrm{CH}_{2}-\right), 1.98\left(\mathrm{br}, 4 \mathrm{H}, \mathrm{CH}_{\text {aliphatic }}\right), 4.00\left(\mathrm{t}, 4 \mathrm{H},-\mathrm{OCH}_{2} \mathrm{CH}_{2}-\right)$ ) $4.41(\mathrm{t}, 4 \mathrm{H}$, $-\mathrm{CH}_{2} \mathrm{CH}_{2} \mathrm{~N}-$ ) $, 6.92\left(\mathrm{~d}, 4 \mathrm{H}, \mathrm{H}_{\text {arom }}\right), 6.98(\mathrm{~d}, 2 \mathrm{H},-\mathrm{CH}=\mathrm{CH}-), 7.56\left(\mathrm{~d}, 4 \mathrm{H}, \mathrm{H}_{\text {arom }}\right), 7.62(\mathrm{~d}, 2 \mathrm{H},-\mathrm{CH}=\mathrm{CH}-$ ), $7.88\left(\mathrm{~d}, 4 \mathrm{H}, H_{\text {arom }}\right), 8.52$ (d, $\left.4 \mathrm{H}, H_{\text {arom }}\right) ;{ }^{13} \mathrm{C} N M R\left(100 \mathrm{MHz}, \mathrm{CDCl}_{3}, \mathrm{ppm}\right) \delta=14.0,22.6,25.4,25.9,27.9$, 28.1, 29.1, 29.2, 29.3, 31.0, 31.7, 60.9, 68.4, 115.2, 119.3, 123.7, 127.0, 130.3, 142.5, 143.2, 154.3, 161.9.

Anal. Calcd for salt II-4, $\mathrm{C}_{58} \mathrm{H}_{78} \mathrm{~N}_{4} \mathrm{O}_{10} \mathrm{~F}_{12} \mathrm{~S}_{4}$ (1347.51): $\mathrm{C}, 51.70 ; \mathrm{H}, 5.83 ; \mathrm{N}, 4.16 ; \mathrm{S}, 9.52$. Found: $\mathrm{C}, 51.83$; $\mathrm{H}, 5.73 ; \mathrm{N}, 4.14 ; \mathrm{S}, 9.45 ;{ }^{1} \mathrm{H}$ NMR $\left(400 \mathrm{MHz}, \mathrm{CDCl}_{3}, \mathrm{ppm}\right) \delta=0.82\left(\mathrm{t}, 6 \mathrm{H},-\mathrm{CH}_{2} \mathrm{CH}_{3}\right), 1.20-1.48(\mathrm{~m}, 34 \mathrm{H}$, $-\mathrm{CH}_{\text {aliphatic }}$ ), $1.78\left(\mathrm{q}, 4 \mathrm{H},-\mathrm{OCH}_{2} \mathrm{CH}_{2} \mathrm{CH}_{2}-\right)$ ) $1.94\left(\mathrm{br}, 4 \mathrm{H}, \mathrm{CH}_{\text {aliphatic }}\right), 3.99\left(\mathrm{t}, 4 \mathrm{H},-\mathrm{OCH}_{2} \mathrm{CH}_{2}-\right)$ ), $4.39(\mathrm{t}, 4 \mathrm{H}$, $-\mathrm{CH}_{2} \mathrm{CH}_{2} \mathrm{~N}-$ ) $, 6.91\left(\mathrm{~d}, 4 \mathrm{H}, \mathrm{H}_{\text {arom }}\right), 6.96(\mathrm{~d}, 2 \mathrm{H},-\mathrm{CH}=\mathrm{CH}-), 7.56\left(\mathrm{~d}, 4 \mathrm{H}, H_{\text {arom }}\right), 7.63(\mathrm{~d}, 2 \mathrm{H},-\mathrm{CH}=\mathrm{CH}-)$, $7.89\left(\mathrm{~d}, 4 \mathrm{H}, H_{\text {arom }}\right), 8.51$ (d, $\left.4 \mathrm{H}, H_{\text {arom }}\right) ;{ }^{13} \mathrm{C} \mathrm{NMR}\left(100 \mathrm{MHz}, \mathrm{CDCl}_{3}, \mathrm{ppm}\right) \delta=14.1,22.7,25.6,26.0,28.3$, 28.6, 29.2, 29.4, 31.2, 31.8, 61.0, 68.4, 115.3, 118.4, 119.4, 121.6, 123.8, 124.8, 127.1, 130.4, 142.6, $143.3,154.5,160.0$. The ${ }^{1} \mathrm{H}$ and ${ }^{13} \mathrm{C}$ NMR spectra of the salts II-1 - II-4 are provided in Figs. S5 - S8. 


\section{Results and discussion}

\subsection{Synthesis of dicationic stilbazolium salts (I-1-I-4 and II-1-II-4)}

The synthesis of salts I-1 - I-4, depicted in Scheme 1, involved the reaction of trans-4'-octyloxy-4stilbazole [63] with $\alpha, \omega$-methylene ditosylates [64], [65] in acetonitrile. Afterwards, their counterions were exchanged with triflimide by metathesis reaction in a common organic solvent to yield the second series of salts, II-1 - II-4 [64], [65]. The chemical structures and the completion of exchange reactions were confirmed by using ${ }^{1} \mathrm{H},{ }^{19} \mathrm{~F}$, and ${ }^{13} \mathrm{C}$ NMR spectra. Trans $-4^{\prime}-$ octyloxy-4-stilbazole [61] and $\alpha, \omega$-methylene ditosylates [60], [61] were synthesized according to the reported procedures. These two molecules were reacted in acetonitrile on heating to reflux for $48 \mathrm{~h}$ to give the desired salts (1-1 - I-4) in 75\%-80\% yields [62]. The crude products were recrystallized from acetonitrile $\left(\mathrm{CH}_{3} \mathrm{CN}\right)$ or methanol $(\mathrm{MeOH})$ to provide fine yellow crystalline dicationic salts. Their chemical structures were confirmed by NMR spectroscopy. The ${ }^{1} \mathrm{H}$ NMR spectrum of compound I1 showed resonances at $\delta=9.03,7.81,7.47,7.10$ and $6.88 \mathrm{ppm}$ for the protons of the aromatic moieties and a set of resonances at $\delta=7.50$ and $6.83 \mathrm{ppm}$ for the alkene protons of the stilbazolium moiety. Two unique triplets of $-\mathrm{OCH}_{2} \mathrm{CH}_{2}-$ and $-\mathrm{CH}_{2} \mathrm{CH}_{2} \mathrm{~N}$-appeared at 3.96 and $4.52 \mathrm{ppm}$, respectively. By changing the aliphatic linkage, additional protons were monitored between 1.25 and $1.50 \mathrm{ppm}$. To exchange the counterions by metathesis reaction, from tosylate to triflimide, each salt I1 - I-4 was further reacted with an excess of lithium triflimide in methanol on heating at reflux. The completion of the anion exchange was confirmed by ${ }^{1} \mathrm{H}$ NMR in which the tosylate protons' peaks totally disappeared, and by ${ }^{19} \mathrm{~F}$ NMR (Fig. S9), where one peak at $-78.84(-79.28,-75.96$ and -75.97$)$ $\mathrm{ppm}$ was observed indicating the presence of triflimide moiety. Furthermore, the ${ }^{13} \mathrm{C}$ NMR spectra provided the additional information on the complete ion exchange. The four aromatic carbons of the tosylate and the methyl carbon were not detected in the ${ }^{13} \mathrm{C} N M R$ spectra. These results unambiguously confirm the successful synthesis of the desired dicationic stilbazolium salts under the experimental conditions used.

\subsection{Thermal properties of dicationic stilbazolium salts I-1 - I-4 to II-1 - II-4}

The thermal properties of the dicationic stilbazolium salts I-1 - I-4 and II-1 - II-4 were investigated by DSC, POM and variable-temperature XRD. Fig. 1 shows the DSC thermograms of the first series of salts, $\mathbf{I} \mathbf{- 1 / 4}$, containing the tosylate counterion. Salts $\mathbf{I} \mathbf{- 1}$ and $\mathbf{I} \mathbf{- 2}$ showed a low-temperature broad endotherm and a high-temperature sharp endotherm, salt I-3 showed a very small low-temperature endotherm and a high-temperature sharp endotherm and salt I-4 showed two low-temperature endotherms (a very small and a broad) and a high-temperature sharp endotherm. The lowtemperature endotherm(s) were related to crystal-to-crystal transitions, which were verified by POM observation of highly birefringent crystal phases as shown in Fig. 2. There were sharp textural defects, but both absence of homogeneity in the domains and absence of fluidity suggest their crystalline character. The high-temperature endotherm in each of these salts was related to the crystal-to-liquid transition $\left(T_{m}\right)$. The $T_{m}$ values of these tosylate salts $\left(221,170,202\right.$ and $187^{\circ} \mathrm{C}$, respectively), found to oscillate around a mean value of ca. $190-200^{\circ} \mathrm{C}$ with the increasing flexibility of the central methylene linkages. The lowest $T_{m}$ of these salts was related to the odd-numbered nine of the central methylene linkage. Thus, the thermal properties of these salts are at variance with the results for several members of an analogous series of dicationic stilbazolium containing mesylate and tosylate as counterions [62]. Moreover, despite of their promesogenic structures, these salts do not display mesomorphic properties, and instead solely exhibit crystalline polymorphism, unlike other stilbazolium salts [45], [46], [47], [48], [49], [50] and stilbazole-containing silver ion metal 
complexes [66], [67], [68], which are reported to show thermotropic LC properties at variable temperatures depending on the nature of substituents.

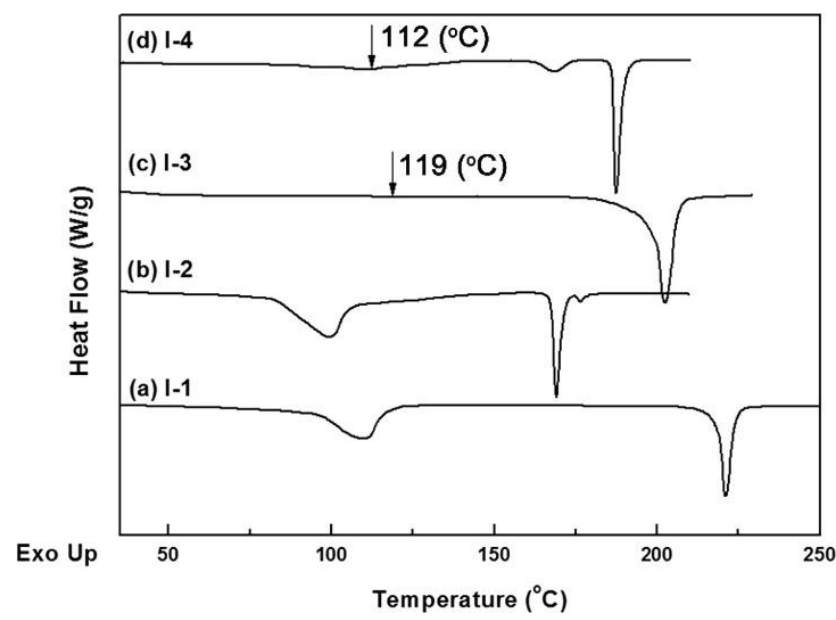

Fig. 1. DSC thermograms of salts I-1 - I-4 obtained at a heating rate of $10^{\circ} \mathrm{C} / \mathrm{min}$.

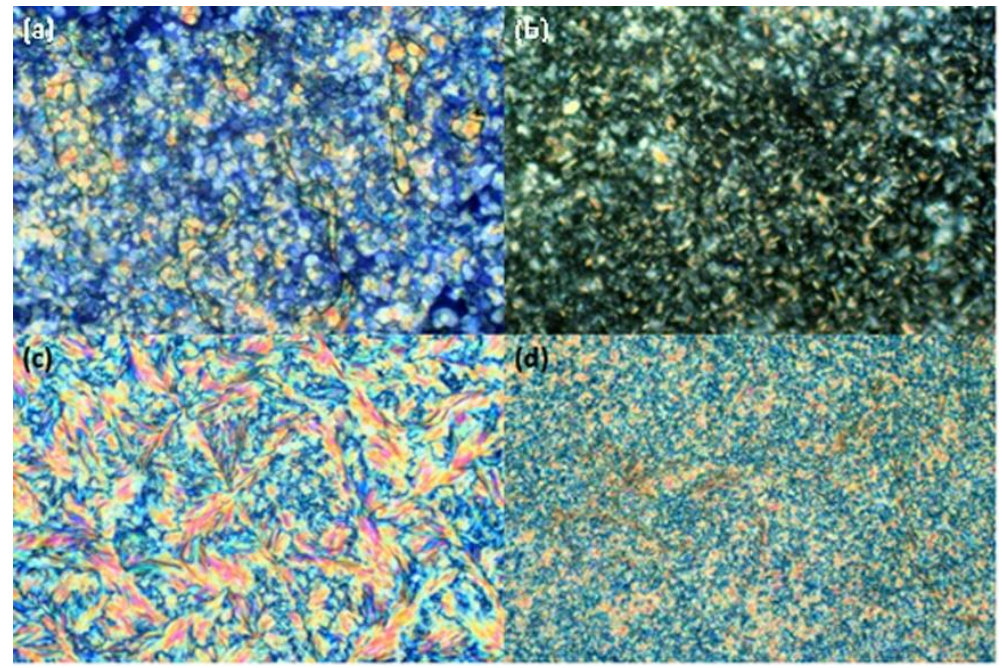

Fig. 2. Photomicrographs of: (a) I-1 taken at $200^{\circ} \mathrm{C}$, (b) I-2 taken at $165^{\circ} \mathrm{C}$, (c) I-3 taken at $192^{\circ} \mathrm{C}$, and (d) I4 taken at $150{ }^{\circ} \mathrm{C}$ under crossed polarizers exhibiting crystal phases (magnification 400x).

The crystal phases of I-1 and I-4 were studied by XRD as a function of the temperature and their X-ray diffraction patterns at various temperatures are shown in Figs. S10 and Fig. 3, respectively. Some crystal modifications were observed between room temperature and the isotropization temperature. Note here that above $155^{\circ} \mathrm{C}$, the X-ray pattern of I-4 is substantially modified, but still reflects the strong crystalline nature of the material. In the cooling run, the material slowly crystallizes, as evidenced by the emergence of several sharp peaks in the wide-angle range, although at different positions.

The DSC thermograms obtained from the first heating cycles of II-1 - II-4 containing triflimide as counterions are shown in Fig. 4. Salt II-1 showed a single sharp endotherm in its first heating cycle of its DSC thermogram. Salt II-2 showed a low-temperature very broad endotherm and a hightemperature sharp endotherm. Each of the salts II-3 and II-4 have two low-temperature endotherms and a high-temperature sharp endotherm in the DSC thermograms. Like the tosylate salts above, the low-temperature endotherm(s) were related to crystal-to-crystal transitions, which were verified by the observation of highly birefringent crystal phases under the polarizing optical microscope, as shown 
in Fig. 5. There were sharp textural defects, and the absence of both homogeneity in the domains and fluidity strongly supported their crystalline nature. The high-temperature endotherm in each of these salts was related to the crystal-to-liquid transition $\left(T_{m}\right)$ that was also verified with POM. The $T_{m}$ values of these triflimide salts (II-1-II-4) $\left(184,129,146\right.$ and $164^{\circ} \mathrm{C}$, respectively), do not follow exactly the same trend as the tosylate salts (no temperature oscillations) with the increasing flexibility of the central methylene linkages, as it decreases first to then slowly rise and converge to the temperature of the shortest system, II-1, but still with lower values. The lowest $T_{m}$ of this series of salts was also related to the odd-numbered nine of the central methylene linkage. The $T_{m}$ values of these triflimide salts substantially lower than those of tosylate salts, and were related to the larger size of triflimide than that of tosylate [1], [61].
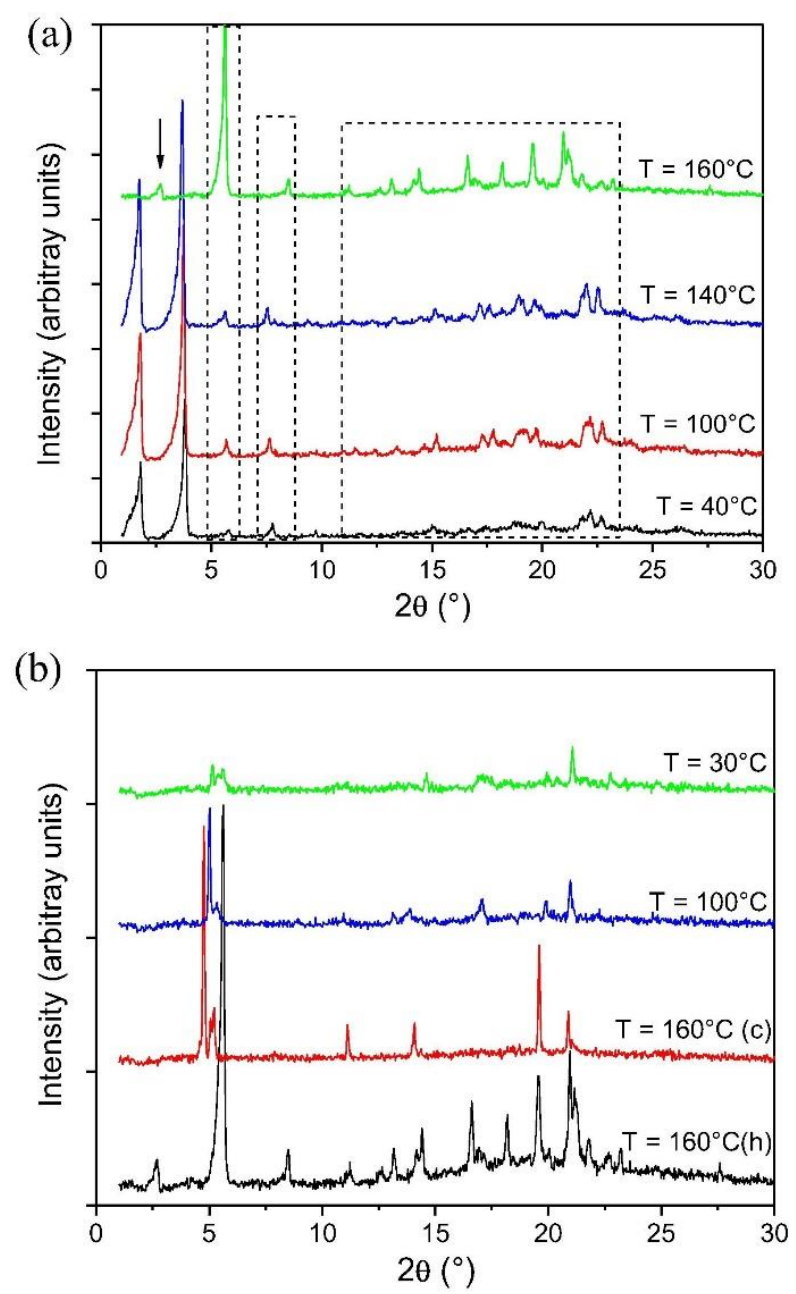

Fig. 3. X-ray diffraction patterns of I-4 recorded on heating (a) and cooling (b) at different temperatures.

The crystal phases of II-3 and II-4 were also studied by XRD and their X-ray diffraction patterns at various temperatures are shown in Figs. S11 and Fig. 6, respectively. For salt II-3, three different crystalline phases are induced before clearing to the isotropic liquid phase. Similarly, various crystalline phases are visible for II-4, with small changes, except for the high-temperature crystalline phase, evidencing important differences from the lower-temperature ones, were observed. On cooling, below, $155^{\circ} \mathrm{C}$, this salt crystallizes. This observation is confirmed by a clear morphological change at about $70^{\circ} \mathrm{C}$. This observation is further supported by Fourier-transform infrared spectroscopy, FT-IR, as a clear morphological change is also detected at about $70^{\circ} \mathrm{C}$ on cooling. 


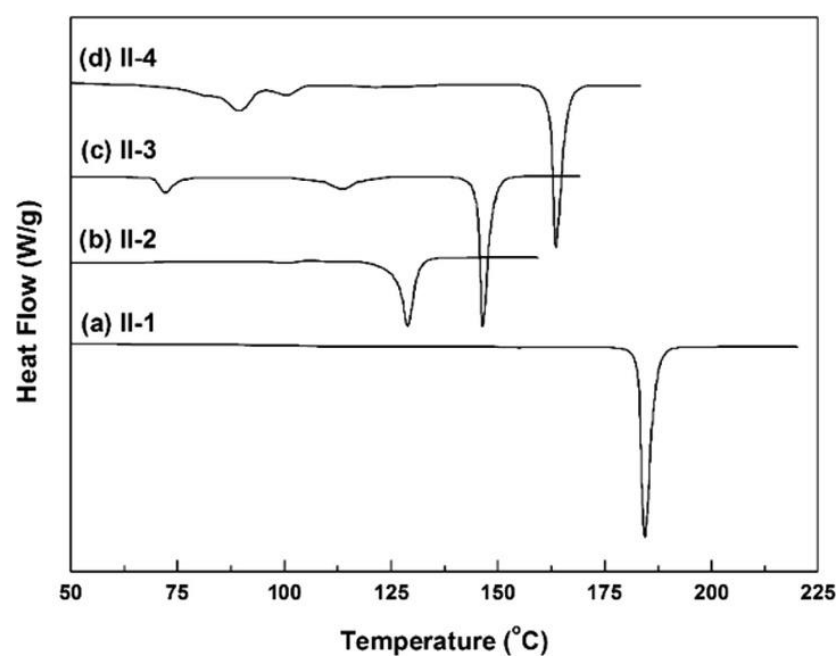

Fig. 4. DSC thermograms of salts II-1 - II-4 obtained at a heating rate of $10^{\circ} \mathrm{C} / \mathrm{min}$.

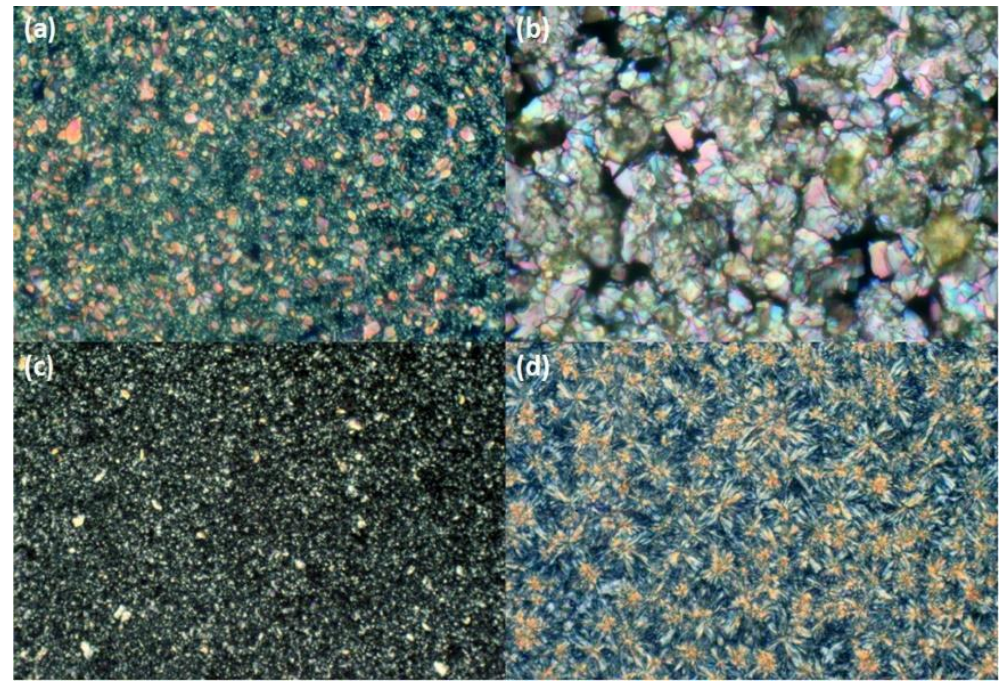

Fig. 5. Photomicrographs of: (a) II-2 taken at $117^{\circ} \mathrm{C}$; (b) II-3 taken at $137^{\circ} \mathrm{C}$; (c) II-4 taken at $130{ }^{\circ} \mathrm{C}$; (d) II-4 taken at $90{ }^{\circ} \mathrm{C}$, on cooling from isotropic liquid under crossed polarizers exhibiting crystal phases (magnification 400x).

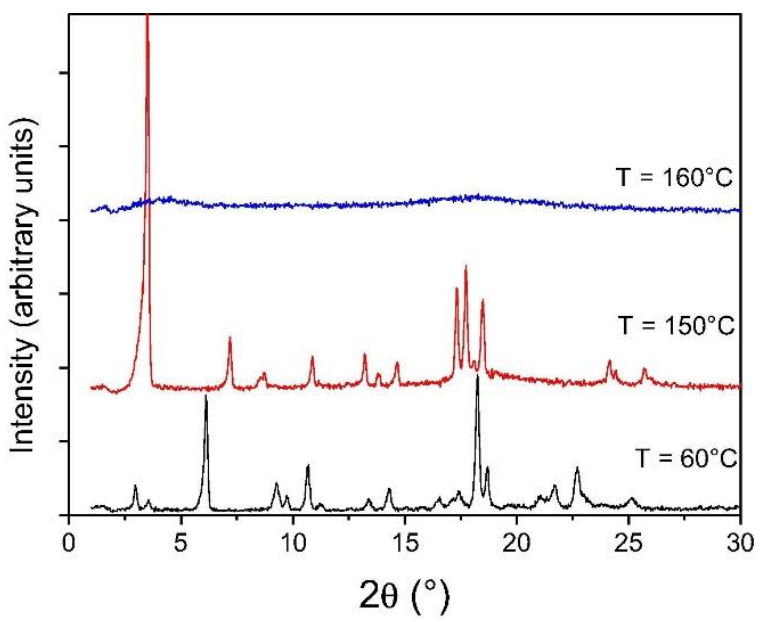

Fig. 6. Photomicrographs of: (a) II-2 taken at $117^{\circ} \mathrm{C}$; (b) II-3 taken at $137^{\circ} \mathrm{C}$; (c) II-4 taken at $130^{\circ} \mathrm{C}$; (d) II-4 taken at $90^{\circ} \mathrm{C}$, on cooling from isotropic liquid under crossed polarizers exhibiting crystal phases (magnification 400x). 
All these thermal properties of the dicationic stilbazolium salts containing both tosylate and triflimide counterions, except II-1, evidenced crystalline polymorphism. The phenomenon is quite common in many ILs and ILCs [45], [46], [47], [48], [49], [50], [69], [70], [71], [72], [73], [74], [75], [76], [77], and is presumably related to various conformations available for both the cationic and anionic moieties.

\subsection{Thermal stabilities of dicationic stilbazolium salts I-1 - I-4 and II-1 - II-4}

Thermal stabilities of dicationic stilbazolium salts $\left(T_{d} S\right)$ were studied by thermogravimetric analysis (TGA), and determined at temperatures at which $5 \%$ weight loss of each of the salts occurred at a heating rate of $10^{\circ} \mathrm{C} / \mathrm{min}$ in nitrogen. Their thermogravimetric curves are displayed in Fig. 7 . The $\mathrm{T}_{d} \mathrm{~S}$ of I-1 - I-4 were in the temperature range of 300-309 ${ }^{\circ} \mathrm{C}$. However, after exchanging the tosylate counterions to triflimide counterions for II-1-II-4, their $T_{d} S$ values were increased by ca $60{ }^{\circ} \mathrm{C}$, with an average temperature of $366-367{ }^{\circ} \mathrm{C}$. These results are related to the fact that the $T_{d}$ of lithium triflimide $\left(363^{\circ} \mathrm{C}\right)$ is higher than that of sodium tosylate $\left(155^{\circ} \mathrm{C}\right)$, which affects the thermal stability of this class of dicationic stilbazolium salts. Moreover, triflimide counterion is less nucleophilic than tosylate and, therefore, can act as a nucleophile at high temperature resulting in higher $\mathrm{T}_{\mathrm{d}}$ [78], [79], [80].
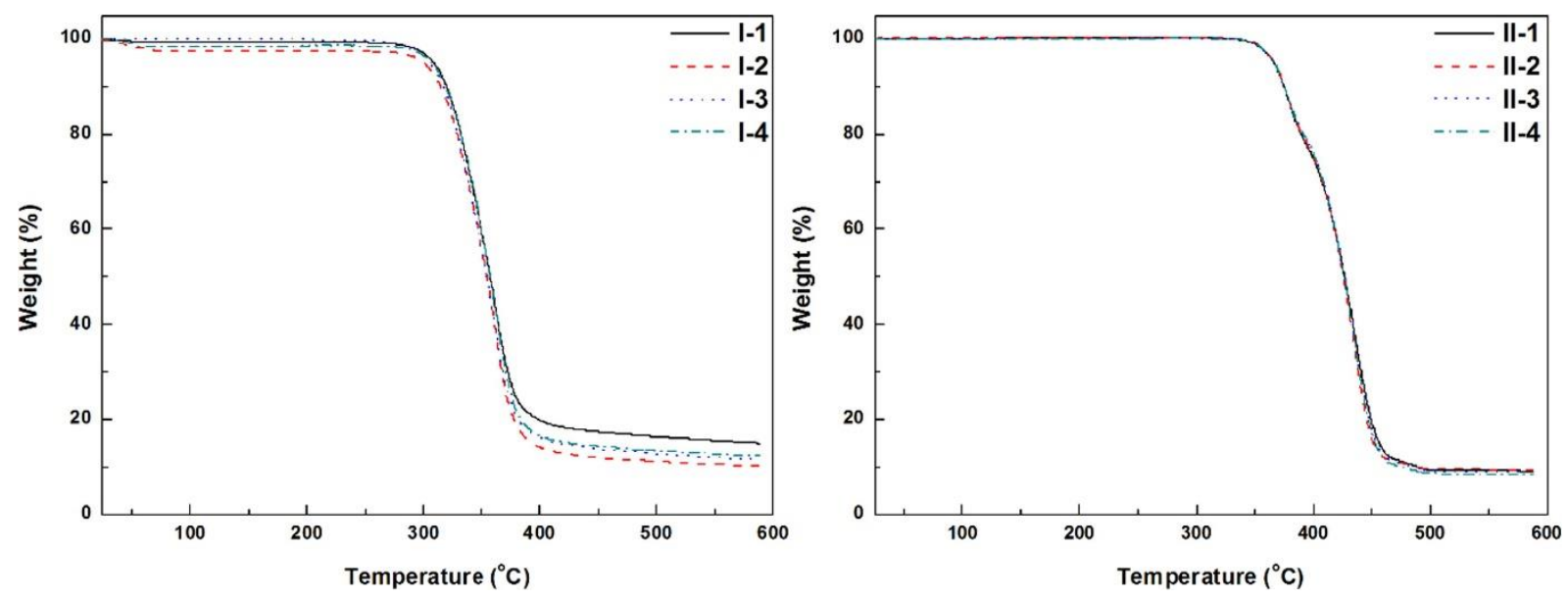

Fig. 7. TGA plots of salts I-1 - I-4 (Left) and salts II-1 - II-4 (Right) obtained at a heating rate of $10^{\circ} \mathrm{C} / \mathrm{min}$ in nitrogen.

\subsection{Optical properties of dicationic stilbazolium salts I-1 - I-4 and II-1 - II-4}

Because stilbazolium moieties have inherent luminescent properties, optical properties of these dicationic salts were examined by UV - Vis and photoluminescent spectroscopies both in solution in various organic solvents and in the solid state. In solution, they showed a broad UV absorption peak $\lambda_{\max }$ varying from 384 to $413 \mathrm{~nm}$ with increasing solvent polarities, i.e., from chloroform $\begin{array}{lll}\left(\mathrm{E}_{\mathrm{T}}(30)=39.1 \mathrm{kcal} / \mathrm{mol}\right) \text {, tetrahydrofuran (THF) } & \left(\mathrm{E}_{\mathrm{T}}(30)=37.4 \mathrm{kcal} / \mathrm{mol}\right), \quad \text { methanol }\end{array}$ $\left(\mathrm{E}_{\mathrm{T}}(30)=55.5 \mathrm{kcal} / \mathrm{mol}\right), \quad$ acetonitrile $\quad\left(\mathrm{E}_{\mathrm{T}}(30)=46.0 \mathrm{kcal} / \mathrm{mol}\right)$ to dimethyl sulfoxide (DMSO) $\left(\mathrm{E}_{\mathrm{T}}(30)=45.0 \mathrm{kcal} / \mathrm{mol}\right)$ [81]. For example, salt $\mathrm{I}-1$ showed a $\lambda_{\max }$ peak at 398, 389, 393, 390, and $386 \mathrm{~nm}$, respectively. Note here that it had the highest $\lambda_{\max }$ peak in chloroform. Similarly, all other salts exhibited highest $\lambda_{\max }$ peaks in this solvent that ranged from 399 to $413 \mathrm{~nm}$. These results are indicative of the composite spectra of $\pi-\pi^{*}$ and $n-\pi^{*}$ transitions that are common to their chemical structures. Furthermore, exchange of counterion to triflimide had minor effects on their UV - Vis spectra in all the solvents examined, except in chloroform the highest $\lambda_{\max }$ peaks were found in the range $407-413 \mathrm{~nm}$, suggesting that no significant change in their ground states occurs in these solvents. Their $\lambda_{\max }$ peaks in various organic solvents are also the composite of the increased $\pi-\pi^{*}$ transition with the increase 
in solvent polarity (bathochromic shift) and of the decreased $n-\pi^{*}$ transitions with the increase in solvent polarity (hypsochromic shift). The measured molar absorption coefficients of salts I-1, I-4, II$\mathbf{3}$ and II-4 in acetonitrile, calculated from the respective Beer-Lambert plots were large and found to be $35056,50608,48,542$ and $51894 \mathrm{M}^{-1} \mathrm{~cm}^{-1}$, respectively (Table 1). The absorption spectra of several salts in methanol $\left(10^{-6} \mathrm{M}\right)$ are provided in Fig. S12.

Table 1. Optical properties of selected dicationic stilbazolium salts.

\begin{tabular}{|c|c|c|c|c|c|c|}
\hline Salts & $\lambda^{a}{ }_{\max }(\mathrm{nm})$ & $\begin{array}{l}\varepsilon \\
\left(\mathrm{M}^{-1} \mathrm{~cm}^{-1}\right)\end{array}$ & $\begin{array}{l}\text { Solution } \lambda^{a}{ }^{\mathrm{em}} / \\
\lambda_{\mathrm{ex}}(\mathrm{nm})\end{array}$ & $\begin{array}{c}\text { Solution } \\
\text { AQYab (\%) }\end{array}$ & $\begin{array}{c}\text { Powdered } \\
\text { AQY }(\%)\end{array}$ & $\begin{array}{l}\text { Thin Film } \lambda \wedge_{\mathrm{c}}^{\mathrm{em}} / \\
\lambda_{\mathrm{ex}}(\mathrm{nm})\end{array}$ \\
\hline I-1 & 386 & 35,056 & $503 / 385$ & 0.86 & 32.61 & $478 / 390$ \\
\hline $1-4$ & 385 & 50,608 & $502 / 385$ & 0.64 & 39.17 & $512 / 340$ \\
\hline II-3 & 386 & 48,542 & $501 / 385$ & 0.74 & 16.92 & $477 / 390$ \\
\hline II-4 & 387 & 51,894 & $502 / 385$ & 0.68 & 2.87 & $509 / 355$ \\
\hline
\end{tabular}

${ }^{a}$ Measured in acetonitrile $\left(10^{-6} \mathrm{M}\right) .{ }^{\mathrm{b}} \mathrm{Absolute}$ quantum yield was measured by an integration sphere. ${ }^{\mathrm{c}} \mathrm{Cast}$ from chloroform solutions $\left(10^{-6} \mathrm{M}\right)$.

Figure S13 shows the emission spectra of I-1-1-4 recorded in methanol at various excitation wavelengths. Each of them exhibited a narrow emission spectrum without any vibrational fine structures with a single $\lambda_{\mathrm{em}}$ peak as well as narrow full-width at half-maximum (fwhm) value. Note here that emission spectra were independent of the excitation wavelengths used for the measurements. Their $\lambda_{\text {em }}$ peaks are in the narrow range of $484-488 \mathrm{~nm}$ in this polar solvent. Emission spectra recorded for II-1-II-4 in methanol were essentially identical to one another and are displayed in Figure S14. Their $\lambda_{\mathrm{em}}$ peaks are also in the narrow range of $485-487 \mathrm{~nm}$ in this polar solvent. Additionally, their emission spectra in other organic solvents including $\mathrm{CHCl}_{3}, \mathrm{THF}, \mathrm{CH}_{3} \mathrm{CN}$, and DMSO were recorded and are displayed in Fig. S15-Fig. S22. For example, I-1 containing tosylate as counterions showed $\lambda_{\text {em }}$ peaks at $459,477,488,488$, and $490 \mathrm{~nm}$ in $\mathrm{CHCl}_{3}, \mathrm{THF}, \mathrm{MeOH}, \mathrm{CH}_{3} \mathrm{CN}$ and DMSO with excitation wavelengths at $392,390,393,383$ and $387 \mathrm{~nm}$, respectively. Similarly, II-1 containing triflimide counterions displayed $\lambda_{\mathrm{em}}$ peaks at $465,478,485,490$, and $489 \mathrm{~nm}$ in the increased polarity of organic solvents with excitation wavelengths $407,387,385,392$, and $385 \mathrm{~nm}$, respectively. The excitation spectra of the salts in various organic solvents when monitored at their $\lambda_{\text {em }}$ peaks were recorded and are displayed in Fig. S23 and Fig. S24. From these photoluminescence results, on changing the solvent polarity from relatively low polar solvent $\left(\mathrm{CHCl}_{3}\right)$ to high polar solvent (DMSO), bathochromic shift was distinctly observed for all these dicationic salts suggestive of the known positive solvatochromic effect [82], [83]. This property may be related to the fact that a change in the solvent polarity can lead to differential stabilization of the ground and excited states resulting in a change in the energy gap between these electronic states. After exchanging counterion to triflimide, no significant changes in $\lambda_{\text {em }} s$ were observed indicating that hydrophobicity and size of counterion had a negligible effect on their emission spectra. The length of aliphatic linkages between the stilbazolium moieties, like the effect of counterions, did not affect to a great extent their emission spectra in various organic solvents examined. Note here that some dicationic pyridinium salts containing flexible spacers show $\lambda_{\text {em }}$ peaks near $360 \mathrm{~nm}$, i.e., in the UV region at the excitation wavelengths of $280-290 \mathrm{~nm}$ in dichloromethane that are independent of counterions used [84].

The emission spectra of salts I-1 - II-4 in their solid state were also recorded in thin films cast from $\mathrm{CHCl}_{3}$ solutions onto quartz slides and displayed in Figure $\mathrm{S} 25$ to explore their potential applications in optoelectronic devices. Their emission spectra were quite broad without any vibrational fine 
structures and with broad fwhm values when compared with those of their solutions spectra. Salts I$1-1-4$ exhibited $\lambda_{\text {em }}$ peaks at 478, 525, 522, and $512 \mathrm{~nm}$ when excited at 390, 342, 340, and $340 \mathrm{~nm}$ wavelengths of light, respectively. Similarly, salts II-1 - II-4 in thin films also cast from $\mathrm{CHCl}_{3}$ exhibited $\lambda_{\text {em }}$ peaks at 455, 551, 477, and $509 \mathrm{~nm}$ when excited at 390, 348, 390, and $355 \mathrm{~nm}$ wavelengths of light, respectively. In general, there was a red shift for all these salts, except for II-1, which suggest that they had more ordered structures in the solid state when compared with those of their solutions spectra recorded in chloroform (Table 1). This red shift in the solid state was related to the $\pi-\pi$ stacking interactions of aromatic moieties of stilbazolium salts in their solid state. The red shift values as well as fwhm values of tosylate salts were wider than those of triflimide salts in general indicative of that fact that there existed more ordered structures in the solid-state for tosylate salts than those in the triflimide salts [77]. The highest red shifts were observed for I-2 and even for II-2 triflimide containing counterions suggesting of the fact that nine methylene units (odd number) between the stilbazolium moieties presumably allowed better $\pi-\pi$ stacking interactions than those of even number of methylene units present in other dicationic salts (odd-even effect). Our results of redshifted emission of these salts in the film states are in excellent agreement with those of dicationic pyridinium salts with flexible spacers [84].

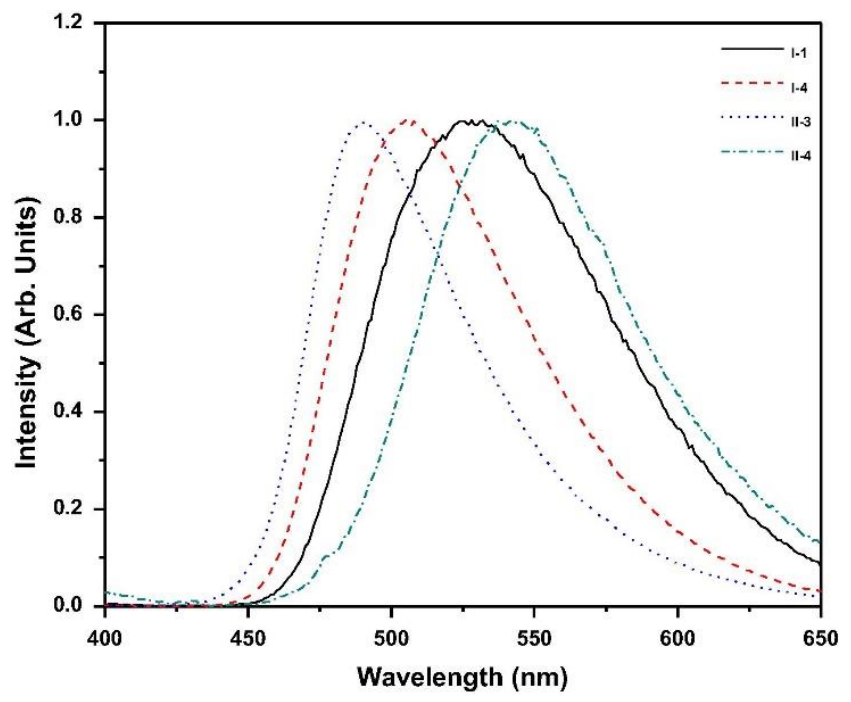

Fig. 8. Emission spectra of films of I-1, I-4, II-3 and II-4, excited at $397 \mathrm{~nm}$.

Fig. 8 shows the emission spectra of as synthesized salts (I-1, I-4, II-3 and II-4) and their $\lambda_{\text {em }}$ peaks were $528,505,490$ and $542 \mathrm{~nm}$ at excitation wavelength of $397 \mathrm{~nm}$. We also calculated the absolute quantum yields of these salts in acetonitrile and as synthesized powdered forms. Interestingly enough, the solution quantum yields were low and found to be $0.86,0.64,0.74$ and $0.68 \%$, but in powdered forms they were high and found to be $32.61,39.17,16.92$ and $2.87 \%$, respectively (Table 1). Note here that the measured relative quantum yields of some dicationic pyridinium salts containing flexible spacers in dichloromethane are also low, which are in the range of $0.5-4.4 \%$ [84]. Generally, quantum yields are low in solid state because of aggregation-caused quenching (ACQ), but the quantum yields are high in solutions because aggregation phenomena do not occur. The emission of light in the solid state is called aggregation-induced emission (AIE) that has been studied for many organic luminophores for the last two decades or so [85], [86]. This phenomenon is explained based on intramolecular rigidification because of intermolecular interactions including restricted intramolecular rotation and restricted intramolecular vibrations. These interactions provide the mechanisms for the decrease of non-radiative pathways thus favoring for radiative pathways for the excited molecules to lose energy [85], [86]. With these limited data of these salts, we cannot provide 
any mechanism for AIE. Suffice to state that these salts in the solid state favor the radiative pathways over the nonradiative pathways resulting this phenomenon. In this regard, these salts are promising for the potential applications in optoelectronic technology [45], [46], [47], [48], [49], [50].

\subsection{Dielectric response and conductivity.}

We now apply complex impedance spectroscopy to study the dielectric and conductivity responses of selected salts from the two series: I-1, I-4, II-3 and II-4, in frequency sweeps at different isothermal steps when cooling from their isotropic phases. We measured the complex dielectric permittivity, $\varepsilon *=\varepsilon^{\prime}-i \varepsilon^{\prime \prime}$, which was then converted into complex impedance, $Z *$, and conductivity, $\sigma *$, using: [87]

(1) $Z^{*}=Z^{\prime}+i Z^{\prime \prime}=1 / i \omega C_{0} \varepsilon^{*}$

and,

(2) $\sigma^{*}=i \omega \varepsilon_{0} \varepsilon^{*}$

where $\mathrm{i}=\mathrm{V}-1$ is the imaginary unit, $\omega$ is the angular frequency in rad.s-1, $\mathrm{C}_{0}$ is the cell capacitance and $\varepsilon_{0}$ is the permittivity in the vacuum, $8.854 \times 10^{-12} \mathrm{Fm}^{-1}$. The direct current conductivity, $\sigma_{\mathrm{dc}}$, was estimated from the plateaus in the double $\log$ arithmic $\log \left(\sigma^{\prime}\right)$ vs $\log (f)$ plots, where $f$ is the frequency, in Hertz.
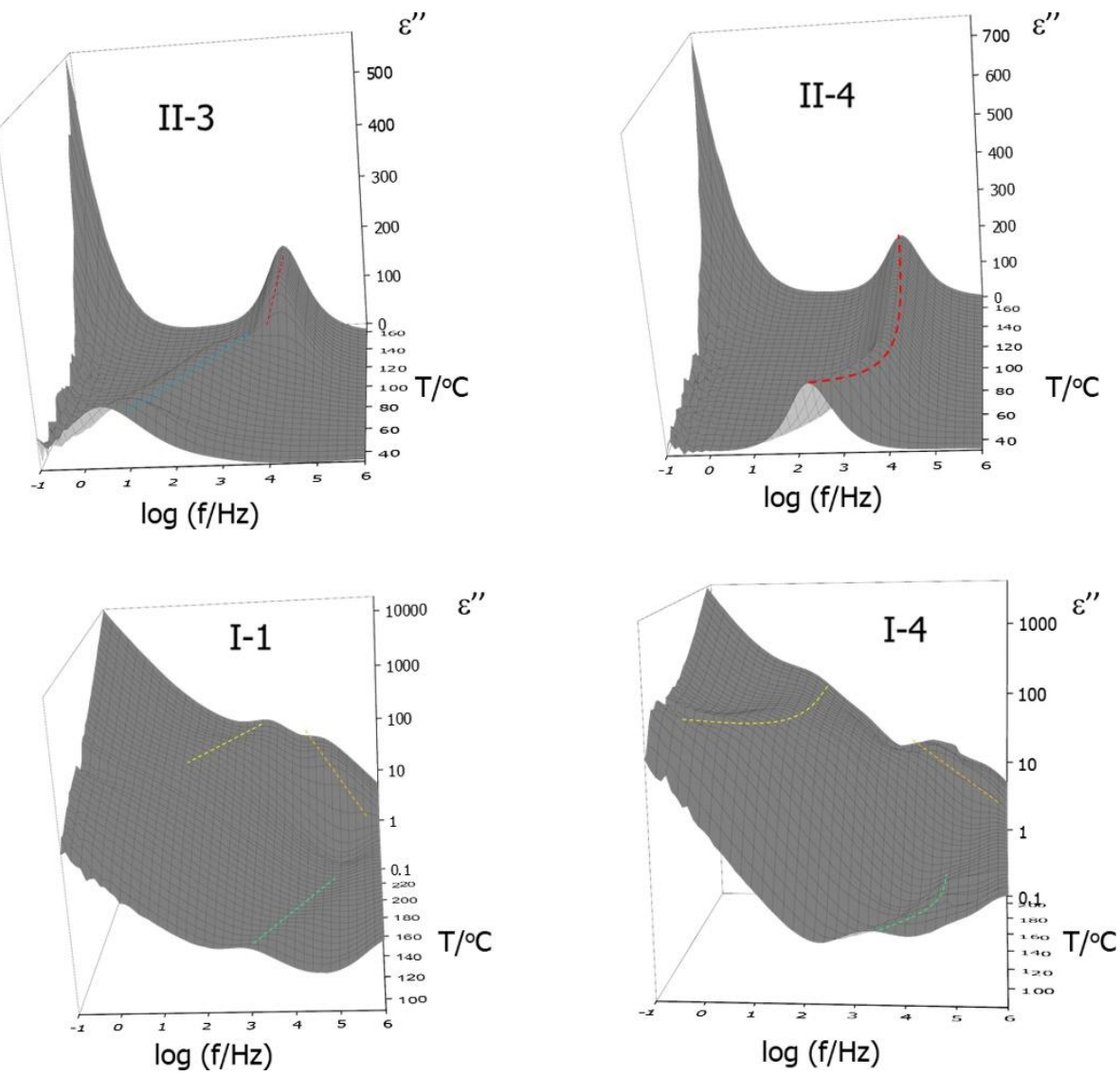

Fig. 9. Three-dimensional plots showing the dielectric loss factor, $\varepsilon^{\prime \prime}$, measured for the triflimide (II-3 and II-4) and tosylate (I-1, I-4) salts as a function of temperature and frequency. Dotted lines indicate maxima of dielectric process. 
Fig. 9 summarizes the dielectric response of the four salts under study through the three-dimensional plots of their loss modulus, $\varepsilon^{\prime \prime}$, as a function of frequency and temperature. The triflimide $\left(\mathrm{N}(\mathrm{Tf})_{2}\right)$ salts, II-3 and II-4, depict one dielectric process at high temperatures (red lines in Fig. 9) with small temperature dependence. On further cooling II-4, this process is continued whilst in the case of II-3, it seems to be replaced by a new relaxation (blue line in Fig. 9). We believe that these results evidence different behavior of these two salts inside the measuring cells: whilst II-3 crystallizes at sufficiently low temperatures, which is confirmed by the temperature-dependent Fourier-Transform Infrared, spectra, FT-IR, obtained for this sample between $\mathrm{KBr}$ discs, see Fig. S26, the longer alkyl chains of I3 preclude long-range ordering, and this salt vitrifies. The suppression of crystallization in II-4 opposes to the calorimetric results in Fig. 1 , and can be explained by the small thickness $(8 \mu \mathrm{m})$ of the dielectric cells.

With the aim to study the thermal dependence of such dielectric processes and their effect on conductivity, we have obtained isothermal plots of the dielectric elastic constant, $\varepsilon^{\prime}$, the loss modulus, $\varepsilon^{\prime \prime}$, and the real component of the conductivity, $\sigma^{\prime}$, and in Fig. 10 we illustrate the results for II-3. Analogous plots are shown for the rest of salts in Fig. S27 to S29. Both the dielectric elastic constant, $\varepsilon^{\prime}$, and loss modulus, $\varepsilon^{\prime \prime}$, have very high values, Fig. 10(a) and 10(b), respectively, explained by the large polarity of ILs [88]. The II-3 $\varepsilon^{\prime \prime}$ peak in the isotropic range starts decreasing in intensity below crystallization $\left(\mathrm{T}<140^{\circ} \mathrm{C}\right)$, and the new process reported above simultaneously appears and shifts to lower frequencies on further cooling, which is indicative of dielectric relaxations associated to molecular motions in the salt [89]. The activation energy, $E_{a}$, of this process (blue line in Fig. 9) can be calculated by fitting the maxima of the loss modulus in Fig. 10(b), $\varepsilon^{\prime \prime}$ max, to an Arrhenius expression,

(3) $\ln \left(f \varepsilon^{\prime \prime}{ }_{\max } / \mathrm{Hz}\right)=\operatorname{lnf} f_{0}-E_{a} / R T$

where $f_{0}$ is the preexponential factor, $R$ is the gas constant, and $T$ is the absolute temperature. The strongly linear temperature dependence of this relaxation, Fig. S30, is indicative of local variations of the II-3 dipoles activated by molecular motions, and more specifically, the $E_{a}$ value $\sim 80 \mathrm{~kJ} \mathrm{~mol}^{-1}$, is typical of the so-called $\beta$-relaxation arising from rotation of rigid dipoles around the long axis of rodlike molecules [88], [90]. Interestingly, the presence of plateaus in $\sigma^{\prime}$ with mirroring

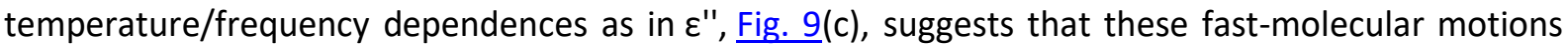
promote short-range conductivity, associated to the presence of the triflimide counterion [91], [92].
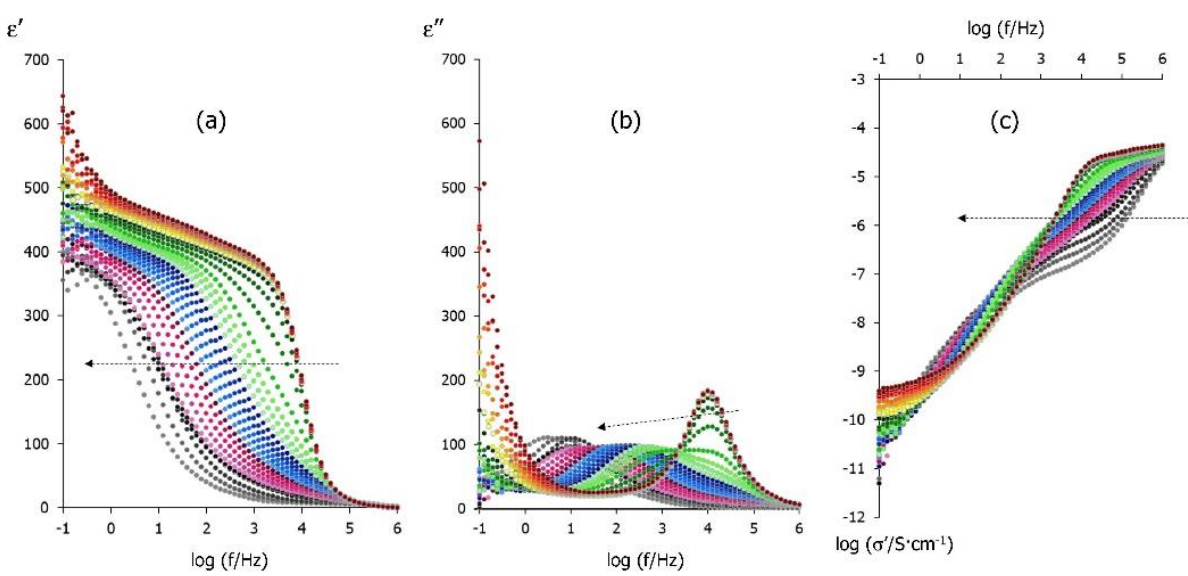

Fig. 10. Dielectric and conductivity response of II-3 as a function of the frequency, measured at different temperatures on cooling from $\mathrm{T}=160^{\circ} \mathrm{C}$ to room temperature $\left(T=32{ }^{\circ} \mathrm{C}\right)$ : (a) dielectric elastic constant, $\varepsilon^{\prime}$; (b) loss modulus, $\varepsilon^{\prime \prime}$; (c) real component of the complex conductivity, $\sigma^{\prime}$. Arrows indicate direction on cooling. 
At sufficiently low frequencies and high temperatures, the dielectric loss rises due to the prominence of long-range ionic conductivity (see plateaus in Fig. 10(c)), with the ionic charges having sufficient time to diffuse between electrodes. The relaxation observed in II-3 (red line in Fig. 9), follows a Vogel-Fulcher-Taman type frequency/temperature dependence [93], [94], and we obtained the corresponding kinetic parameters by fitting the $\varepsilon^{\prime \prime}$ maxima to the following expression, see Fig. $\underline{\text { S31 }}(\mathrm{a})$,

$$
\text { (4) } \ln \left(f^{\prime \prime}{ }_{\max } / \mathrm{Hz}\right)=\operatorname{lnf} f_{0}-B /\left(T-T_{0}\right)
$$

where $f_{0}$ is the frequency in the limit of high temperatures, $B$ is related to the activation energy of the dielectric relaxation, and $T_{0}$ is the Vogel temperature, above which molecular motions onset. The VFT parameters are summarized in Table S1, and are comparable to those reported by our group on asymmetric viologen bistriflimide salts [88]. The marked VFT profiles highlight the relevance of segmental motions in the II-3 glass, which also control the short-range conductivity of this salt visible in Fig. S27(c).

The values for the dielectric loss modulus of the two selected salts containing tosylate ions, I-1 and I4, are larger than those of the triflimide salts, II-3 and II-4, and show more complex profiles, associated to the additional aromatic groups. In Fig. 9 we can discriminate at least two $\varepsilon^{\prime \prime}$ processes for these salts. Both I-1 and I-4 show one main process at high temperatures that shifts to lower frequencies on cooling, and, similarly to the triflimide-containing salts, this can be ascribed to molecular relaxations occurring within polar regions. This process was then fitted to either Arrhenius (I-1) or VFT (I-4) expressions, confirming the tendency towards vitrification at longer terminal chains, see Figs. S32 and S33. The $E_{a}$ value obtained for the linear main process of I-1 $\left(143.7 \mathrm{~kJ} \mathrm{~mol}^{-1}\right)$ is larger than that found for II-3 (79.8 $\mathrm{kJ} \mathrm{mol}^{-1}$ ) and highlights the role of the counterion on the dipole rearrangements. It is worth mentioning that the secondary process for $\mathbf{I - 1}$ has a similar activation energy to the main process $\left(147.1 \mathrm{~kJ} \mathrm{~mol}^{-1}\right)$, which reflect similar molecular motions related to the aromatic groups of the tosylate ions.

All these dielectric relaxations promote short-range conductivity in the salts, and the $\sigma_{\mathrm{dc}}$ values were estimated from Fig. 10(c), Fig. S27(c), Fig. S28(c) and Fig. S29(c). Interestingly, the tosylate salts did not develop clear plateaus in the $\log \left(\sigma^{\prime}\right)$ vs $\log (f)$ plots, despite their stronger dielectric response mentioned above, and we believe that the presence of bulky aromatic groups may hinder the transport of charges by limiting the mobility around the ionic polar sites [95], [96], [97]. These results are also consistent with the bulk aggregation effects in these salts observed in the optical results, caused by strong $\pi-\pi$ interactions. The triflimide salts, on the other hand, exhibit clearer DC conductivity regions, Fig. 10(c) and Fig. S27(c), and their response is dependent on the spacer length. Whilst II3 only show plateaus at the isotropic melt $\left(\sigma_{\mathrm{dc}} \sim 10^{-5} \mathrm{~S} \cdot \mathrm{cm}^{-1}\right)$ and near room temperature $\left(\sigma_{\mathrm{dc}} \sim 10^{-7} / 10^{-6} \mathrm{~S} \cdot \mathrm{cm}^{-1}\right), \mathrm{II}-4$ displays $\mathrm{DC}$ conductivity through all the temperature range under study, with maxima of $\sigma_{\mathrm{dc}} \sim 10^{-4.5} \mathrm{~S} \cdot \mathrm{cm}^{-1}$ in the melt, which decrease following a VFT behavior, see Fig. 11 . These results highlight that transport of ionic charges in stilbazolium salts may need an amorphous environment, even if it happens in the short molecular range, and also that the dielectric and conductivity responses are coupled to segmental motions [93], [94]. Despite being promising, the conductivity values obtained in this work are still two-fold smaller than benchmark ionic liquid electrolytes [98], and phosphonium or imidazolium-based ionic liquids $\left(10^{-2} \mathrm{~S} \mathrm{~cm}^{-1}\right.$, at $\left.30^{\circ} \mathrm{C}\right)$ [99]. The introduction of light responsive elements to promote local motions through reversible conformational changes [100], as well as the alignment of conductivity pathways via liquid crystalline regions [101], [102], [103], [104], will be explored as strategies to increase conductivity at low temperatures in triflimide salts derived from this study. 


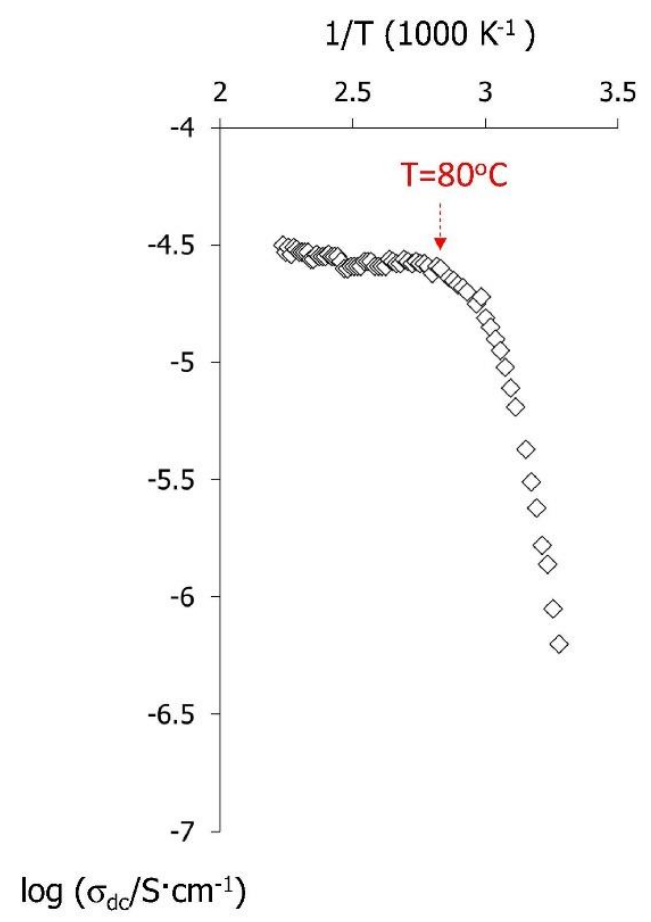

Fig. 11. Arrhenius plot corresponding to the thermal activation of DC conductivity values, $\sigma_{\mathrm{dc}}$, measured for II-4.

\section{Conclusions}

TIn summary, new dicationic stilbazolium salts containing tosylate as counterions were synthesized and their tosylate counterions were then subsequently exchanged to triflimide counterions via metathesis to yield a second series of dicationic salts. Their chemical structures were fully characterized by ${ }^{1} \mathrm{H},{ }^{19} \mathrm{~F}$, and ${ }^{13} \mathrm{C}$ NMR spectroscopy. The thermal transitions and stability of the dicationic salts were studied by DSC, polarizing optical microcopy and TGA analyses. Their luminescence properties were studied by UV-Vis and photoluminescent spectrometry in solutions of several organic solvents of varying polarity, and in the bulk. They exhibited positive solvatochromism effect, and their solid-state emission spectra bathochromic shifts because of $\pi-\pi$ stacking interactions of stilbazolium moieties. These shifts were dependent on the nature of both chemical structures and counterions. The presence of polar tosylate and fluorine groups promotes notable direct current conductivity in the triflimide salts, associated to local motions around the dicationic stilbazolium units. Conductivity is facilitated in glassy domains of the salts, whose morphology can be controlled by slight variations in the length of the molecular flexible spacer between the rigid aromatic moieties. The high quantum yields, and promising conductivities measured in the bulk, open new and exciting possibilities to design dicationic salts with tailored nanostructures and functionalities as optoelectronic devices and sensors.

\section{Declaration of Competing Interest}

The authors declare that they have no known competing financial interests or personal relationships that could have appeared to influence the work reported in this paper. 


\section{Acknowledgement}

This research is in part supported by the NSF EPSCOR RING-TRUE III grant no. 0447416, NSF-SBIR grant no. OII-0610753, NSF-STTR grant no. IIP-0740289 and NASA GRC contract no. NNX10CD25P (PKB). BD and BH thank the CNRS and University of Strasbourg. AMF would like to acknowledge the Carnegie Trust for the Universities of Scotland, for the Research Incentive Grant RIG008586, the Royal Society and Specac Ltd., for the Research Grant RGS\R1\201397, the Royal Society of Chemistry for the award of a mobility grant (M19-0000), and the Royal Society of Edinburgh and the Scottish Government, for the award of a SAPHIRE project.

\section{Appendix A. Supplementary material}

Supplementary data to this article can be found online at https://doi.org/10.1016/j.molliq.2021.117311.

\section{References}

[1] T. Welton, Room-temperature ionic liquids. Solvents for synthesis and catalysis, Chem. Rev. 99 (8) (1999) 2071-2084.

[2] J.P. Hallett, T. Welton, Room-temperature ionic liquids: solvents for synthesis and catalysis. 2, Chem Rev. 111 (2011) 3508-3576.

[3] T. Welton, lonic liquids: a brief history, Biophys. Rev. 10 (2018) 691-706.

[4] X. Han, D.W. Armstrong, Using geminal dicationic ionic liquids as solvents for high-temperature organic reactions, Org. Lett. 7 (19) (2005) 4205-4208.

[5] Dickinson, M.E. Williams, S.M. Hendrickson, H. Masui, R.W. Murray, Hybrid redox polyether melts based on polyether-tailed counterions, J. Am. Chem. Soc. 121 (4) (1999) 613-616.

[6] C. Lagrost, D. Carrié, M. Vaultier, P. Hapiot, Reactivities of some electrogenerated organic cation radicals in room-temperature ionic liquids: toward an alternative to volatile organic solvents?, J Phys. Chem. A 107 (2003) $745-752$.

[7] K.P. Doyle, C.M. Lang, K. Kim, P.A. Kohl, Dentrite-free electrochemical deposition of Li-Na alloys from an ionic liquid electrolyte, J. Electrochem. Soc. 153 (7) (2006) A1353, https://doi.org/10.1149/1.2199444.

[8] C.Y. Wang, V. Mottaghitalab, C.O. Too, G.M. Spinks, G.G. Wallace, Polyaniline and polyaniline-carbon nanotube composite fibres as battery materials in ionic liquid electrolyte, J. Power Sources 163 (2) (2007) 1105-1109.

[9] D.R. MacFarlane, N. Tachikawa, M. Forsyth, J.M. Pringle, P.C. Howlett, G.D. Elliott, J.H. Davis Jr., M. Watanabe, P. Simon, C.A. Angell, Energy application of ionic liquids, Energy Environ. Sci. 7 (2014) 232-250.

[10] M. Watanabe, M.L. Thomas, S. Zhang, K. Ueno, T. Yasuda, K. Dokko, Application of ionic liquids to energy storage and conversion materials and devices, Chem. Rev. 117 (10) (2017) 7190-7239.

[11] A. Basile, M. Hilder, F. Makhlooghiazad, C. Pozo-Gonzalo, D.R. MacFarlane, P.C. Howlett, M. Forsyth, Ionic liquids and organic plastic crystals: advanced electrolytes for safer high performance sodium energy storage technologies, Adv. Energy Mater. 8 (2018) 1703491. 
[12] A.-E. Jiménez, M.-D. Bermúdez, lonic liquids as lubricants for steel-aluminum contacts at low and elevated temperatures, Tribology Lett. 26 (1) (2007) 53-60.

[13] S. Chun, S.V. Dzyuba, R.A. Bartsch, Influence of structural variation in roomtemperature ionic liquids on the selectivity and efficiency of competitive alkali metal salt extraction by a crown ether, Anal. Chem. 73 (15) (2001) 3737-3741.

[14] S. Carda-Broch, A. Berthod, D.W. Armstrong, Solvent properties of the 1-butyl-3-methylimidazolium hexafluorophosphate ionic liquid, Anal. Bioanal. Chem. 375 (2) (2003) 191-199.

[15] R. Germani, M.V. Mancini, G. Savelli, N. Spreti, Mercury extraction by ionic liquids: temperature and alkyl chain length effect, Tetrahedron Lett. 48 (2007) 1767-1769.

[16] D.W. Armstrong, L.-K. Zhang, L. He, M.L. Gross, lonic Liquids as matrixes for matrix-assisted laser desorption/ionization mass spectrometry, Anal. Chem. 73 (15) (2001) 3679-3686.

[17] S. Carda-Broch, A. Berthod, D.W. Armstrong, lonic matrices for matrixassisted laser desorption/ionization time-of-flight detection of DNA oligomers, Rapid Commun. Mass Spectro. 17 (6) (2003) 553-560.

[18] A. Tholey, E. Heinzle, lonic (liquid) matrices for matrix-assisted laser desorption/ionization mass spectrometry-applications and perspectives, Anal. Bioanal. Chem. 386 (1) (2006) 24-37.

[19] K.R. Seddon, Ionic liquids for clean technology, J. Chem. Tech. Biotechnol. 68 (4) (1997) 351-356.

[20] R.D. Rogers, G.A. Voth, Ionic liquids, Acc. Chem. Res. 40 (11) (2007) 1077- 1078.

[21] J.F. Wishart, Energy applications of ionic liquids, Energy Environ. Sci. 2 (9) (2009) 956, https://doi.org/10.1039/b906273d.

[22] E.W. Castner Jr., J.F. Wishart, Spotlight on ionic liquids, J. Chem. Phys. 132 (2010) 120901.

[23] B. Liu, N. Jin, The applications of ionic liquids as functional materials: a review, Curr. Org. Chem. 20 (2016) 2109-2116.

[24] M. Kar, N.V. Plechkova, K.R. Seddon, J.M. Pringle, D.R. MacFarlane, lonic liquids -further progress on the fundamental issues, Aust. J. Chem. 72 (2) (2019) 3, https://doi.org/10.1071/CH18541.

[25] H. Shirota, T. Mandai, H. Fukazawa, T. Kato, Comparison between dicationic and monocationic ionic liquids: Liquid density, thermal properties, surface tension, and shear viscosity, J. Chem. Eng. Data 56 (2011) 2453-2459.

[26] C. Rizzo, F. D’Anna, R. Neto, Functionalized diimidazolium salts: the anion effect on the catalytic activity, RSC Adv. 6 (2016) 58477-58484.

[27] F. Billeci, F. D’Anna, S. Marullo, R. Noto, Self-assembly of fluorescent diimidazolium salts: tailor properties of the aggregates changing alkyl chain features, RSC Adv. 6 (2016) 59502-59512.

[28] M. Talebi, R.A. Patil, D.W. Armstrong, Physicochemical properties of branched-chain dicationic ionic liquids, J. Mol. Liq. 256 (2018) 247-255.

[29] A.Z. Halimehjani, V. Barati, Synthesis of Novel tetracationic ammonium salts and their applications as catalyst for the synthesis of xanthenes, benzoxanthenes and bis(indolyl)methanes in water, Chem. Select 3 (11) (2018) 3024-3028.

[30] A.Z. Halimehjani, V. Barat, M. Karimi, Synthesis of a novel tetracationic acidic organic salt based on DABCO and its applications as catalyst in the Knoevenagel condensation reactions in water, Synth. Commun. 49 (5)

(2019) 724-734. 
[31] S. Marullo, C. Rizzo, F. D'Anna, Task-specific organic salts and ionic liquids binary mixtures: a combination to obtain 5-hydroxymethylfurfural from carbohydrates, Front. Chem. 7 (2019) 134.

[32] C.F. Poole, S.K. Poole, lonic liquid stationary phases for gas chromatography, J. Sep. Sci. 34 (8) (2011) 888900.

[33] C. Ragonese, D. Sciarrone, P.Q. Tranchida, P. Dugo, L. Mondello, Use of ionic liquids as stationary phases in hyphenated gas chromatography techniques, J. Chromatrogr. A 1255 (2012) 130-144.

[34] R.A. Patil, M. Talebi, L.M. Sidisky, A. Berthod, D.W. Armstrong, Gas chromatography selectivity of new phosphonium-based dicationic ionic liquid stationary phases, J. Sep. Sci. 41 (22) (2018) 4142-4148.

[35] R. Engel, J.I. Cohen, Organic polycationic salts-syntheses and applications, Curr. Org. Chem. 6 (2002) 1453-1467.

[36] S. Lall, V. Behaj, D. Mancheno, R. Casiano, M. Thomas, A. Rikin, J. Gaillard, R. Raju, A. Scumpia, S. Castro, R. Engel, J.I. Cohen, Polycations-12. The Synthesis of liquid ionic phosphates (LIPS) from mono- and polycationic ammonium halides, Synthesis (11) (2002) 1530-1540, https://doi.org/10.1055/s-2002-33333.

[37] J.F. Wishart, S.I. Lall-Ramnarine, R. Raju, A. Scumpia, S. Bellevue, R. Ragbir, R. Engel, Effects of functional group substitution on electron spectra and solvation dynamics in a family of ionic liquids, Radiat. Phys. Chem. $72(2-3)(2005)$ 99-104.

[38] K. Ito, N. Nishina, H. Ohno, Enhanced ion conduction in imidazolium-type molten salts, Electrochim. Acta 45 (8-9) (2000) 1295-1298.

[39] M. Yoshizawa, K. Ito-Akita, H. Ohno, Evidence of interaction between anion and polyether in the bulk, Electrochim. Acta 45 (10) (2000) 1617-1621.

[40] J.L. Anderson, R. Ding, A. Ellern, D.W. Armstrong, Structure and properties of high stability geminal dicationic ionic liquids, J. Am. Chem. Soc. 127 (2) (2005) 593-604.

[41] F. D’Anna, R. Noto, Di- and tricationic organic salts: an overview of their physical properties and applications, Eur. J. Org. Chem. 4201-4223 (2014).

[42] T. Payagala, Y. Zhang, E. Wanigasekara, K. Huang, Z.S. Breitbach, P.S. Sharma, L.M. Sidisky, D.W. Armstrong, Trigonal tricationic ionic liquids: a generation of gas chromatographic stationary phases, Anal. Chem. 81 (2009) 160-173.

[43] P.S. Sharma, T. Payagala, E. Wanigasekara, A.B. Wijeratne, J. Huang, D.W. Armstrong, Trigonal tricationic ionic liquids: molecular engineering of trications to control physicochemical properties, Chem. Mater. 20 (2008) 4182-4184.

[44] M. Trilla, R. Pleixats, T. Parella, C. Blanc, P. Dieudonné, Y. Guari, M.W.C. Man, lonic liquid crystals based on mesitylene-containing bis- and trisimidazolium salts, Langmuir 24 (1) (2008) 259-265.

[45] K. Binnemans, Ionic liquid crystals, Chem. Rev. 105 (11) (2005) 4148-4204.

[46] K.V. Axenov, S. Laschat, Thermotropic ionic liquid crystals, Materials 4 (1) (2011) 206-259.

[47] A. Alvarez Fernandez, P. Kouwer, Key developments in ionic liquid crystals, Int. J. Mol. Sci. 17 (5) (2016) 731, https://doi.org/10.3390/ijms17050731.

[48] K. Goossens, K. Lava, C.W. Bielawski, K. Binnemans, lonic liquid crystals: versatile materials, Chem. Rev. 116 (2016) 4643-4807.

[49] D. Devadiga, T.N. Ahipa, Recent synthetic advances in pyridine-based thermotropic mesogens, RSC Adv. 9 (40) (2019) 23161-23228. 
[50] K. Salikolimi, A.A. Sudhakar, Y. Ishida, Functional ionic liquid crystals, Langmuir 36 (40) (2020) 1170211731.

[51] A.J. Boydson, P.D. Vu, O.L. Dykhno, V. Chang, A.R. Wyatt II, A.S. Stockett, E.T. Ritschdorff, J.B. Shear, C.W. Bielawski, Modular fluorescent benzobis (imidazolium) salts: syntheses, photophysical analyses, and applications, J. Am. Chem. Soc. 130 (2008) 3143-3156.

[52] D. Qin, R. Sullivan, W.F. Berkowitz, R. Bittman, S.A. Rotenberg, Inhibition of protein kinase Ca by dequalinium analogues: dependence on linker length and geometry, J. Med. Chem. 43 (2000) 1413-1417.

[53] C. Abeywickrama, S.A. Rotenberg, A.D. Baker, Inhibition of protein kinase C by dequalinium analogues: structure-activity studies on head group variations, Bioorg. Med. Chem. 14 (2006) 7796-7803.

[54] J.L.R. WILLIAMS, S.K. WEBSTER, J.A.V. ALLAN, cis and trans isomers of 2-styrylpyridine, J. Org. Chem. 26 (12) (1961) 4893-4895.

[55] K. Takagi, B.R. Suddaby, S.L. Vadas, C.A. Backer, D.G. Whitten, Topological control of reactivity by interfacial orientation: excimer fluorescence and photodimerization of 4-stilbazolium cations in aerosol OT reversed micelles, J. Am. Chem. Soc. 108 (1986) 7865-7867.

[56] H.S. Banu, A. Lalitha, K. Pitchumani, C. Srinivasan, Modification of photochemical reactivity of trans-2styrylpyridine: effect of cyclodextrin complexation, Chem. Commun. 607-608 (1999).

[57] X.-H. Li, L.-Z. Wu, L.-P. Zhang, C.-H. Tung, Controlled photocyclization, photodimerization, and membranes, Org. Lett. 4 (2002) 1175-1177.

[58] H. Maeda, R.-I. Hiranabe, K. Mizuno, Intramolecular photocycloaddition of bstilbazoles tethered by silyl chains, Tetrahedron Lett. 47 (45) (2006) 7865- 7869.

[59] Z. Yang, S. Aravazhi, A. Schneider, P. Seiler, M. Jazbinsek, P. Günter, Synthesis and crystal growth of stilbazolium derivatives for second-order nonlinear optics, Adv. Funct. Mater. 15 (7) (2005) 1072-1076.

[60] S. Kannan, A. Sekar, K. Sivaperuman, Effects of the molecular structure on the second-order nonlinear optical properties of stilbazolium derivative single crystals: a review, J. Mater. Chem. C 8 (47) (2020) 1666816690.

[61] T.S. Jo, W.L. McCurdy, O. Tanthmanatham, T.K. Kim, H. Han, P.K. Bhowmik, B. Heinrich, B. Donnio, Synthesis and characterization of luminescent tricationic salts of mesitylene and stilbazolium moieties, J. Mol. Struc. 1019 (2012) 174-182

[62] P. Cheng, A. Blumstein, S. Subramanyam, Novel ion containing liquid crystals and liquid crystalline main chain polymers based on trans-1,2-bis(4-pyridyl)ethylene mesogen, Mol. Cryst. Liq. Cryst. 269 (1995) 1-38.

[63] U. Kumar, T. Kato, J.M.J. Frechet, Use of intermolecular hydrogen bonding for the induction of liquid crystallinity in the side chain of polysiloxanes, J. Am. Chem. Soc. 114 (17) (1992) 6630-6639.

[64] P.K. Bhowmik, A.H. Molla, H. Han, M.E. Gangoda, R.N. Bose, Lyotropic liquid crystalline main-chain viologen polymers: Homopolymer of 4,40-bipyridyl with the ditosylate of trans-1,4-cyclohexanedimethanol and its copolymers with the ditosylate of 1,8-octanediol, Macromolecules 31 (1998) 621-630.

[65] P.K. Bhowmik, S. Akhter, H. Han, Thermotropic liquid crystalline main-chain viologen polymers, J. Polym. Sci. Part A: Polym. Chem. 33 (11) (1995) 1927- 1933.

[66] D.W. Bruce, D.A. Dunmur, E. Lalinde, P.M. Maitlis, P. Styring, Novel types of ionic thermotropic liquid crystals, Nature 323 (6091) (1986) 791-792. 
[67] D.W. Bruce, D.A. Dunmur, S.A. Hudson, E. Lalinde, P.M. Maitlis, M.P. McDonald, R. Orr, P. Styring, A. Cherodian, R.M. Richardson, J.L. Feijoo, G. Ungar, Polymorphic ionic mesogens of silver(I): ionic materials exhibiting a thermotropic cubic mesophase, Mol. Cryst. Liq. Cryst. 206 (1991) 79-92.

[68] D.W. Bruce, Calamitics, cubics, and columnars - Liquid-crystalline complexes of silver(I), Acc. Chem. Res. 33 (12) (2000) 831-840.

[69] J. Golding, S. Forsyth, D.R. MacFarlane, M. Forsyth, G.B. Deacon, Methanesulfonate and ptoluenesulfonate salts of the $\mathrm{N}$-methyl-Nalkylpyrrolidinium and quaternary ammonium cations: novel low cost ionic liquids, Green Chem. 4 (2002) 223-229.

[70] J. De Roche, C.M. Gordon, C.T. Imrie, M.D. Ingram, A.R. Kennedy, F. Lo Celso, A. Triolo, Application of complementary experimental techniques to characterization of the phase behavior of [C16mim][PF6] and [C14mim][PF6], Chem. Mater. 15 (16) (2003) 3089-3097.

[71] M. Herstedt, W.A. Henderson, M. Smirnov, L. Ducasse, L. Servant, D. Talaga, J. C. Lassègues, Conformational isomerism and phase transitions in tetraethylammonium bis(trifluoromethanesulfonyl)imide Et4NTFSI, J. Mol. Struc. 783 (1-3) (2006) 145-156.

[72] P.K. Bhowmik, H. Han, I.K. Nedeltchev, J.J. Cebe, S.-W. Kang, S. Kumar, Synthesis and characterization of ionic liquids: viologen bis\{tetrakis[3,5-bis(trifluoromethyl)phenyl]borate\} salts, Liq. Cryst. 33 (2006) 891-906.

[73] T. Cardinaels, K. Lava, K. Goossens, S.V. Eliseeva, K. Binnemans, 1,10-Phenanthrolinium ionic liquid crystals, Langmuir 27 (5) (2011) 2036-2043.

[74] T. Endo, K. Fujii, K. Nishakawa, Crystal polymorphism of 1-butyl-3-methylimidazoliumhexafluorophosphate: phase diagram, structure, and dynamics, Aust. J. Chem. 72 (2019) 11-20.

[75] M. Lee, Y.-H. Lee, J.H. Park, U.H. Choi, Bis-imidazolium iodide organic ionic plastic crystals and their applications to solid state dye-sensitized solar cells, Org. Electron. 48 (2017) 241-247.

[76] H. Chae, Y.-H. Lee, M. Yang, W.-J. Yoon, D.K. Yoon, K.-U. Jeong, Y.H. Song, U.H. Choi, M. Lee, Interesting phase behaviors and ion-conducting properties of dicationic $\mathrm{N}$-alkylimidazolium tetrafluoroborate salts, RSC Adv. 9 (7) (2019) 3972-3978.

[77] H. Chae, A.R. Lee, M. Yoon, U.H. Choi, G. Park, M. Lee, Organic ionic crystals: solid-phase structure and thermal properties of dicationic a, x-bis[N, NO-(4-alkylpyridinium)]alkane hexafluorophosphate salts, Asian J. Org. Chem. 8 (2019) 1718-1725.

[78] A.K. Nedeltchev, H. Han, P.K. Bhowmik, Design and synthesis of photoactive ionic amorphous molecular materials, J. Mater. Chem. 21 (34) (2011) 12717, https://doi.org/10.1039/c1jm11735a.

[79] T.S. Jo, A.K. Nedeltchev, B. Biswas, H. Han, P.K. Bhowmik, Synthesis and characterization of poly(pyridinium salt)s derived from various diamines, Polymer 53 (2012) 1063-1071.

[80] T.S. Jo, J.J. Koh, H. Han, P.K. Bhowmik, Solution, thermal and optical properties of bis(pyridinium salt)s ionic liquids, Mater. Chem. Phys. 139 (2013) 901-910.

[81] C. Reichardt, Empirical parameters of solvent polarity as linear free-energy relationships, Angew. Chem. Int. Engl. 18 (2) (1979) 98-110.

[82] P. Suppan, N. Ghoneim, Solvatochromism, Royal Society of Chemistry, Cambridge, UK, 1997, p. 96 (Chapter 4).

[83] J.R. Lakowicz, Principles in Fluorescence Spectroscopy, 3rd ed., Springer, New York, NY, 2006, p. 63 (Chapter 3) 
[84] A. Pană, M. Ilis, T. Staicu, I. Pasuk, V. Cîrcu, Columnar bis(pyridinium) ionic liquid crystals derived from 4hydroxypyridine: synthesis, mesomorphism and emission properties, Liq. Cryst. 43 (2016) 381-392.

[85] S. Xu, Y. Duan, B. Liu, Precise molecular design for high-performance luminogens with aggregation-induced emission, Adv. Mater. 32 (1) (2020) 1903530, https://doi.org/10.1002/adma.201903530.

[86] A.C.B. Rodrigues, J.S.S. de Melo, Aggregation-induced emission: from small molecules to polymershistorical background, mechanisms and photophysics, Top. Curr. Chem. 379 (2021) 15.

[87] J.C. Dyre, Some remarks on ac conduction in disordered solids, J. Non Cryst. Solids 135 (2-3) (1991) 219226.

[88] P.K. Bhowmik, O. Noori, S.L. Chen, H. Han, M.R. Fisch, C.M. Robb, A. Variyam, A. Martinez-Felipe, Ionic liquid crystals: synthesis and characterization via NMR, DSC, POM, X-ray diffraction and ionic conductivity of asymmetric viologen bistriflimide salts, J. Mol. Liq. 328 (2021) 115370.

[89] A. Martínez-Felipe, L. Santonja-Blasco, J.D. Badia, C.T. Imrie, A. Ribes-Greus, Characterization of functionalized side-chain liquid crystal methacrylates containing nonmesogenic units by dielectric spectroscopy, Ind. Eng. Chem. Res. 52 (26) (2013) 8722-8731.

[90] R. Zentel, G.R. Strobl, H. Ringsdorf, Dielectric-relaxation of liquid-crystalline polyacrylates and polymethacrylates, Macromolecules 18 (5) (1985) 960-965.

[91] Z. Wojnarowska, J. Knapik, M. Diaz, A. Ortiz, I. Ortiz, M. Paluch, Conductivity mechanism in polymerized imidazolium-based protic ionic liquid [HSO3-BVIm][OTf]: dielectric relaxation studies, Macromolecules 47 (2014) 4056-4065.

[92] A.W. Brown, A. Martinez-Felipe, lonic conductivity mediated by hydrogen bonding in liquid crystalline 4-nalkoxybenzoic acids, J. Mol. Struct. 1197 (2019) 487-496.

[93] H. Vogel, The temperature dependence law of the viscosity of fluids, Phys. Z. 22 (1921) 645-646.

[94] G.S. Fulcher, Analysis of recent measurements of the viscosity of glasses - reprint, J. Am. Ceram. Soc. 75 (5) (1992) 1043-1055.

[95] K. Kishimoto, T. Suzawa, T. Yokota, T. Mukai, H. Ohno, T. Kato, Nanosegregated polymeric film exhibiting high ionic conductivities, J. Am. Chem. Soc. 127 (44) (2005) 15618-15623.

[96] A. Concellón, S. Hernández-Ainsa, J. Barberá, P. Romero, J.L. Serrano, M. Marcos, Proton conductive ionic liquid crystalline poly(ethyleneimine) polymers functionalized with oxadiazole, RSC Adv. 8 (66) (2018) 37700-

37706.

[97] S. Liang, M.V. O’Reilly, U.H. Choi, H.-S. Shiau, J. Bartels, Q. Chen, J. Runt, K.I. Winey, R.H. Colby, High ion content siloxane phosphonium ionomers with very low T-g, Macromolecules 47 (13) (2014) 4428-4437.

[98] A. Jourdain, A. Serghei, E. Drockenmuller, Enhanced ionic conductivity of a 1,2,3-triazolium-based poly(siloxane ionic liquid) homopolymer, ACS MacroLett. 5 (11) (2016) 1283-1286.

[99] D. Manaila Maximean, V. Cîrcu, C.P. Ganea, Dielectric properties of abisimidazolium salt with dodecyl sulfate anion doped with carbon nanotubes, Beilstein J. Nanotechnol. 9 (2018) 164-174.

[100] T.S. Velayutham, M.S. Azmina, V. Manickam-Achari, A. Roche, R. Ramesh, A. Martinez-Felipe, A new lightresponsive resistive random-access memory device containing hydrogen-bonded complexes, J. Photochem. Photobiol. A 404 (2021) 112914.

[101] S.M. Alauddin, N.F.K. Aripin, T.S. Velayutham, I. Chaganava, A. Martinez- Felipe, The role of conductivity and molecular mobility on the photoanisotropic response of a new azo-polymer containing sulfonic groups, J. Photochem. Photobiol. A: Chem. 389 (2020) 112268. 
[102] S. Mohd Alauddin, N. Fadhilah Kamalul Aripin, T. Selvi Velayutham, A. Martinez-Felipe, A. Martinez-Felipe, Liquid crystalline copolymers containing sulfonic and light-responsive groups: from molecular design to conductivity, Molecules 25 (11) (2020) 2579, https://doi.org/10.3390/molecules25112579.

[103] L. Vanti, S.M. Alauddin, D. Zaton, N.F.K. Aripin, M. Giacinti-Baschetti, C.T. Imrie, A. Ribes-Greus, A. Martinez-Felipe, Ionically conducting and photoresponsive liquid crystalline terpolymers: towards multifunctional polymer electrolytes, Eur. Polym. J. 109 (2018) 124-132.

[104] S.M. Alauddin, A.R. Ibrahim, N.F.K. Aripin, T.S. Velayutham, O.K. Abou-Zied, A. Martinez-Felipe, New sidechain liquid crystalline terpolymers with anhydrous conductivity: effect of azobenzene substitution on light response and charge transfer, Eur. Polym. J. 146 (2021) 110246. 